Supporting Information

\title{
Formation of giant and small cyclic complexes from a flexible tripeptide ligand controlled by metal coordination and hydrogen bonds
}

Ryosuke Miyake, ${ }^{\dagger, * *}$ Akira Ando, ${ }^{\dagger}$ Manami Ueno,${ }^{\dagger}$ and Takahiro Muraoka ${ }^{\S}$

${ }^{\dagger}$ Department of Chemistry and Biochemistry, Graduate School of Humanities and Sciences, Ochanomizu University

2-1-1 Otsuka, Bunkyo-ku, Tokyo 112-8610, Japan

E-mail: miyake.ryosuke@ocha.ac.jp

¥JST-PRESTO

4-1-8 Honcho, Kawaguchi, Saitama 332-0012, Japan

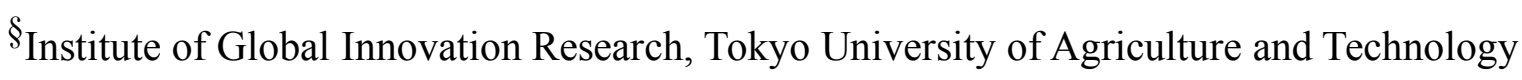

2-24-16 Naka-cho, Koganei, Tokyo 184-8588, Japan 


\section{Contents:}

1. General Experimental Methods

2-1. Synthesis of tripeptide 1

$\mathrm{pS} 3$

$\mathrm{pS} 4$

2-2. Synthesis of $\mathrm{Ni}(\mathrm{II})$ complex of $\mathbf{1}$

pS6

2-3. Additional information for the crystal structures

$\mathrm{pS} 9$

3-1. Additional discussion for crystal structures of cyclic Ni(II) complexes of $\mathbf{1}$

pS13

3-2. Discussion of the conditions required for the formation of the catenane structure

3-3. Comparison of peptide conformation in giant cyclic complexes of $\mathbf{1}$

pS16

pS17

3-4. Additional information concerning the crystal structure of the $\left(1-3 \mathrm{H}^{+}\right)_{4} \mathrm{Ni}_{8}$ complex

pS23

3-5. Additional data for comparison of the peptide conformation between the $\mathbf{1}_{14} \mathrm{Ni}_{14}$ complex and $\left(1-3 \mathrm{H}^{+}\right)_{4} \mathrm{Ni}_{8}$ complex

pS26

3-6. Additional information concerning the packing structure of the plate-like crystals of the $\mathbf{1}_{14} \mathrm{Ni}_{14}$ complex

pS27

3-7. Discussion of the intermolecular interactions between cyclic complexes and the reason for the formation of the ellipsoidal framework

4. Computational study of the large cyclic complex of $\mathbf{1}$

pS29

pS30

5. Additional characterization of cyclic Ni(II) complexes of $\mathbf{1}$

$\mathrm{pS} 31$

6. Characterization of the cyclic $\mathrm{Ni}$ (II) complexes of $\mathbf{1}$ in solution state

pS32

7. References 


\section{General experimental methods}

2,2-Bis(tert-butoxycarbonylaminomethyl)-3-phthalimidopropanoic acid was synthesized according to the reported method. ${ }^{\mathrm{S} 1}$ 1-Ethyl-3-(3-dimethylaminopropyl)carbodiimide hydrochloride (EDCI $\left.\cdot \mathrm{HCl}\right)$ was purchased from the Peptide Institute. $N$-Ethyldiisopropylamine (DIEA), trifluoroacetic acid (TFA), $\mathrm{N}$-hydroxysuccinimide (HOSu), and dehydrated solvents were purchased from Wako Pure Chemicals. $N$-tert-Butoxycarbonyl-glycine (Boc-Gly-OH) and $O$-(7-aza-1H-benzotriazol-1-yl)- $N, N, N^{\prime}, N^{\prime}-$ tetramethyluronium hexafluoroborate (HATU) were purchased from Watanabe Chemical Industries. A solution of $0.5 \mathrm{M} \mathrm{NH}_{3}$ in dioxane was purchased from Sigma-Aldrich. $\mathrm{NH}_{2} \mathrm{NH}_{2} \cdot \mathrm{H}_{2} \mathrm{O}$ was purchased from Kanto Chemical. All reagents and solvents were used without further purification. Universal Premium and Chromatorex silica gel columns for flash chromatography were purchased from Yamazene Corporation and Fuji Silysia Chemical Ltd., respectively. ${ }^{1} \mathrm{H}$ NMR and ${ }^{13} \mathrm{C}$ NMR spectra were measured with a Bruker Advance III. Electrospray ionization-time-of flight (ESI-TOF) mass spectra were recorded on a Thermo Scientific Q Exactive spectrometer for the synthesized peptides and a Waters Xero G2-S QTOF spectrometer for metal complexes. Crystallographic data were collected on a Bruker APEXII CCD detector with Mo- $K \alpha$ radiation $(\lambda=0.71075 \AA$ ). The structures were solved by direct methods using SHELXS. The refinement (on $F^{2}$ ) and graphical structure solution were carried out in the SHELXL program suite. ${ }^{\mathrm{S} 2} \mathrm{UV}$-Vis spectra were recorded on a V-650 spectrometer (JASCO). Infrared spectra and Raman spectra of single crystals were recorded on JASCO IRT-5200 and JASCO NRS5100 spectrometers, respectively. For the measurement of IR spectra, a single crystal was crushed between diamond plates using finger pressure, and the IR spectrum of the crushed sample on the plate was measured. Dynamic light scattering (DLS) measurements were performed with Malvern Zetasizer Nano ZSP, where a 1-cm BRAND disposal UV cuvette was used. 


\section{2-1. Synthesis of tripeptide 1}

Scheme S1. Synthetic scheme of tripeptide 1

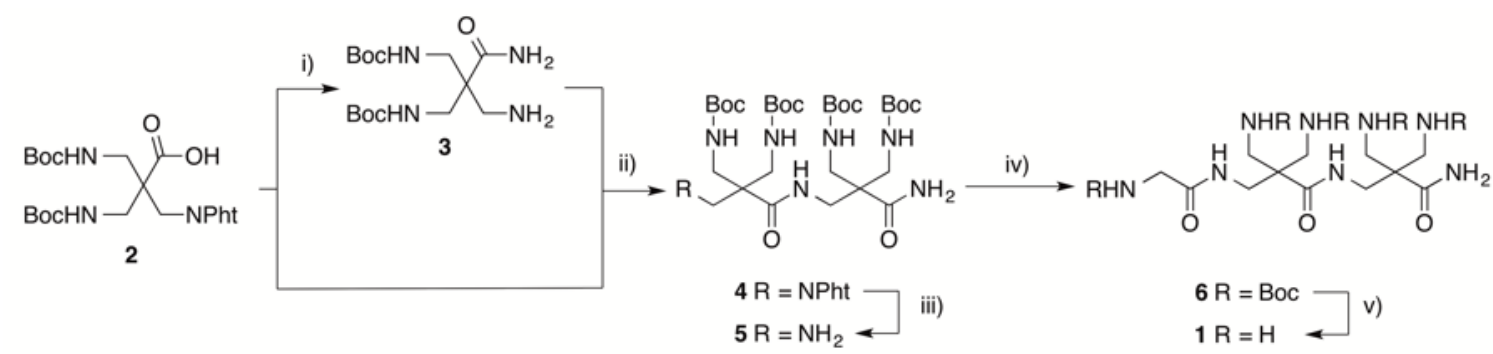

Reagents and Conditions : i) 1) 1.2 eq EDCl $\cdot \mathrm{HCl}, 1.2$ eq hydroxysuccinimide, $\mathrm{CH}_{2} \mathrm{Cl}_{2}$, rt, then 4 eq $\mathrm{NH}_{3}$ in dioxane $\mathrm{rt}$; 2) 4 eq hydrazine monohydrate, EtOH/dioxane, $80^{\circ} \mathrm{C}, 80 \%$ (2 steps) ; ii) 1.0 eq 2, 1.0 eq $3,1.2$ eq $\mathrm{HATU}, 1.5$ eq DIEA, $\mathrm{CH}_{2} \mathrm{Cl}_{2}$, rt, $99 \%$; iii) 4 eq hydrazine monohydrate,

EtOH/dioxane, $80^{\circ} \mathrm{C}, 96 \%$; iv) 1.5 eq Boc-Gly-OH, 1.2 eq HATU, 1.5 eq DIEA, $\mathrm{CH}_{2} \mathrm{Cl}_{2}, \mathrm{rt}, 88 \%$; v) 1) 30 eq $\mathrm{TFA}_{2} \mathrm{CH}_{2} \mathrm{Cl}_{2}, \mathrm{rt}^{2}$ ) ion exchange, $93 \%$.

3: To an ice-cooled solution of 2,2-bis(tert-butoxycarbonylaminomethyl)-3-phthalimidopropanoic acid $(2,1.79 \mathrm{~g}, 3.75 \mathrm{mmol})$ in dry $\mathrm{CH}_{2} \mathrm{Cl}_{2}(37 \mathrm{~mL}), \mathrm{HOSu}(519 \mathrm{mg}, 4.51 \mathrm{mmol})$ and $\mathrm{EDCI} \cdot \mathrm{HCl}(863 \mathrm{mg}$, $4.50 \mathrm{mmol}$ ) were added, and the mixture was stirred at the same temperature for $10 \mathrm{~min}$ and, then, at room temperature for $1 \mathrm{~h}$. The mixture was cooled again in an ice bath, and $0.5 \mathrm{M} \mathrm{NH}_{3}$ in dioxane (30 $\mathrm{mL}, 15 \mathrm{mmol}$ ) was added. After stirring at the same temperature for $10 \mathrm{~min}$ and, then, at room temperature for $1.5 \mathrm{~h}$, the $\mathrm{CH}_{2} \mathrm{Cl}_{2}$ was evaporated to dryness. $\mathrm{CHCl}_{3}(100 \mathrm{~mL})$ was added to the residue, which was washed with $1 \mathrm{M}$ aq. $\mathrm{HCl}$, water, and brine $(100 \mathrm{~mL}$ each). The organic layer was dried over anhydrous $\mathrm{Na}_{2} \mathrm{SO}_{4}$ and evaporated to dryness to afford an intermediate compound ( $2.25 \mathrm{~g}$ ) as a colorless foam. The crude product was used in the next step without further purification.

To a solution of the intermediate compound $(2.25 \mathrm{~g})$ in EtOH $(38 \mathrm{~mL}) /$ dioxane $(19 \mathrm{~mL}), \mathrm{NH}_{2} \mathrm{NH}_{2} \cdot \mathrm{H}_{2} \mathrm{O}$ $(0.73 \mathrm{~mL}, 15 \mathrm{mmol})$ was added, and the mixture was heated to $80^{\circ} \mathrm{C}$ for $4 \mathrm{~h}$. The solvents were then evaporated to dryness, and EtOAc $(100 \mathrm{~mL})$ was added to the residue. The insoluble material was removed by filtration. After the solvent had been evaporated to dryness, the residue was purified by silica gel flash chromatography (Universal Premium L column, $\mathrm{CHCl}_{3}: \mathrm{MeOH}=99: 1-85: 15$ ) to afford $3(1.04 \mathrm{~g}, 80 \%$ in two steps) as a colorless foam.

${ }^{1} \mathrm{H}-\mathrm{NMR}\left(600 \mathrm{MHz}, \mathrm{DMSO}-d_{6}\right) \delta: 7.79\left(\mathrm{~s}, 1 \mathrm{H}, \mathrm{CONH}_{2}\right), 7.00$ (s, $\left.1 \mathrm{H}, \mathrm{CONH}_{2}\right), 6.50$ (t, $2 \mathrm{H}, J=6.3 \mathrm{~Hz}$, BocNH), $3.11\left(\mathrm{dd}, 2 \mathrm{H}, J=14.0,6.4 \mathrm{~Hz}, \mathrm{BocNHCH}_{2}\right), 3.06$ (dd, 2H, $J=14.2,6.6 \mathrm{~Hz}, \mathrm{BocNHCH}_{2}$ ), 2.54 (s, $2 \mathrm{H}, \mathrm{NH}_{2} \mathrm{CH}_{2}$ ), 1.38 (s, 18H, Boc); ${ }^{13} \mathrm{C}-\mathrm{NMR}$ (150MHz, DMSO-d6) $\delta: 175.7,156.4,78.3,52.1$, 43.0, 41.5, 28.3; HRMS (ESI); $m / z=[\mathrm{M}+\mathrm{H}]^{+}$347.2282, $\mathrm{C}_{15} \mathrm{H}_{31} \mathrm{~N}_{4} \mathrm{O}_{5}$ requires 347.2289.

4: To an ice-cooled solution of 2,2-bis(tert-butoxycarbonylaminomethyl)-3-phthalimidopropanoic acid $(2,1.19 \mathrm{~g}, 2.48 \mathrm{mmol})$ and 3 (860 mg, $2.48 \mathrm{mmol})$ in dry $\mathrm{CH}_{2} \mathrm{Cl}_{2}(40 \mathrm{~mL})$, DIEA (484 mg, $\left.3.74 \mathrm{mmol}\right)$ in dry $\mathrm{CH}_{2} \mathrm{Cl}_{2}(2 \mathrm{~mL})$ and $\mathrm{HATU}(1.13 \mathrm{~g}, 2.98 \mathrm{mmol})$ were added. The mixture was stirred at the same temperature for $30 \mathrm{~min}$ and, then, at room temperature for $18 \mathrm{~h}$. After the solvent had been evaporated to dryness, the residue was dissolved in EtOAc $(100 \mathrm{~mL})$, which was washed with saturated aq. 
$\mathrm{NaHCO}_{3}, 0.5 \mathrm{M}$ aq. $\mathrm{KHSO}_{4}$, water, and brine (100 mL each). The organic layer was dried over anhydrous $\mathrm{Na}_{2} \mathrm{SO}_{4}$ and evaporated to dryness. The residue was purified by silica gel flash chromatography (Chromatorex, SI-50, size 120 column, $\mathrm{CHCl}_{3}: \mathrm{MeOH}=100: 0-99: 1-98: 2$, flow rate: $20 \mathrm{~mL} / \mathrm{min})$ to afford $4(1.97 \mathrm{~g}, 99 \%)$ as a colorless foam.

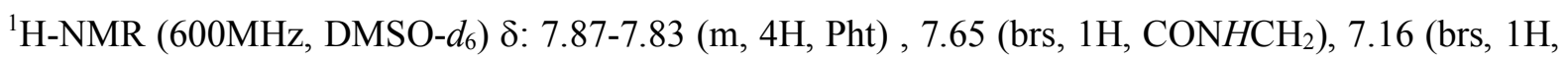
$\mathrm{CONH}_{2}$ ), 7.03 (brs, $1 \mathrm{H}, \mathrm{CONH}_{2}$ ), 6.50 (brs, $4 \mathrm{H}, \mathrm{BocNH}$ ), 3.67 (s, 2H, $\mathrm{PhtNCH}_{2}$ ), 3.35-3.30 (overlapped with $\left.\mathrm{H}_{2} \mathrm{O}\right), 3.21-3.15(\mathrm{~m}, 6 \mathrm{H}), 2.94(\mathrm{dd}, 2 \mathrm{H}, J=14.5,6.2 \mathrm{~Hz})\left(\mathrm{CONHCH}_{2} \mathrm{C}, \mathrm{BocNHCH}_{2}\right), 1.36(\mathrm{~s}, 18 \mathrm{H}$, Boc), 1.34 (s, 18H, Boc); ${ }^{13} \mathrm{C}-\mathrm{NMR}\left(150 \mathrm{MHz}, \mathrm{MeOH}-d_{4}\right) \delta: 177.3,174.7,170.5,158.8,158.8,158.5$, 158.4, 135.6, 133.2, 124.4, 80.7, 80.6, 53.6, 53.3, 42.7, 42.6, 42.4, 42.3, 41.1, 40.9, 28.7; HRMS (ESI): $m / z=[\mathrm{M}+\mathrm{Na}]^{+} 828.4090, \mathrm{C}_{38} \mathrm{H}_{59} \mathrm{~N}_{7} \mathrm{O}_{12} \mathrm{Na}$ requires 828.4114.

5: To a solution of $4(1.96 \mathrm{~g}, 2.43 \mathrm{mmol})$ in EtOH $(25 \mathrm{~mL}) /$ dioxane $(12.5 \mathrm{~mL}), \mathrm{NH}_{2} \mathrm{NH}_{2} \cdot \mathrm{H}_{2} \mathrm{O}(0.47 \mathrm{~mL}$, $9.7 \mathrm{mmol}$ ) was added, and the mixture was heated to $80^{\circ} \mathrm{C}$ for $4 \mathrm{~h}$. The solvents were evaporated to dryness. EtOAc $(100 \mathrm{~mL})$ was added to the residue, and the insoluble material was removed by filtration. After the solvent had been evaporated to dryness, the residue was purified by silica gel flash chromatography (Chromatorex, SI-50, size 120 column, $\mathrm{CHCl}_{3}: \mathrm{MeOH}=99: 1-85: 15$, flow rate: 15 $\mathrm{mL} / \mathrm{min})$ to afford $5(1.58 \mathrm{~g}, 96 \%)$ as off-white foam.

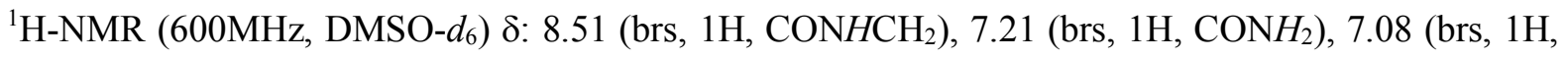
$\mathrm{CONH}_{2}$ ), 6.56 (brt, $2 \mathrm{H}, J=5.6 \mathrm{~Hz}, \mathrm{BocN} H$ ), 6.54 (brt, $2 \mathrm{H}, J=4.7 \mathrm{~Hz}, \mathrm{BocN} H$ ), 3.19 (s, 2H, $\mathrm{CONHCH}_{2}$ ), 3.11-3.04 (m, 8H, BocNHCH$\left.H_{2}\right), 2.57$ (s, 2H, $\left.\mathrm{NH}_{2} \mathrm{CH}_{2}\right), 1.75$ (brs, $\left.2 \mathrm{H}, \mathrm{NH} \mathrm{H}_{2}\right), 1.38$ (s, 18H, Boc), 1.37 (s, 18H, Boc); ${ }^{13} \mathrm{C}-\mathrm{NMR}\left(150 \mathrm{MHz}, \mathrm{MeOH}-d_{4}\right) \delta: 177.5,175.6,159.0,158.8,80.8,80.5$, 54.8, 53.4, 43.0, 42.0, 41.9, 40.9, 28.7; HRMS (ESI): $m / z=[\mathrm{M}+\mathrm{H}]^{+}$676.4212, $\mathrm{C}_{30} \mathrm{H}_{58} \mathrm{~N}_{7} \mathrm{O}_{10}$ requires 676.4240 .

6: To an ice-cooled solution of 5 (676 mg, $1.00 \mathrm{mmol})$ and Boc-Gly-OH (262 mg, $1.50 \mathrm{mmol})$ in dry $\mathrm{CH}_{2} \mathrm{Cl}_{2}(18 \mathrm{~mL})$, DIEA (193 mg, $\left.1.49 \mathrm{mmol}\right)$ in dry $\mathrm{CH}_{2} \mathrm{Cl}_{2}(2 \mathrm{~mL})$ and HATU (458 mg, $\left.1.20 \mathrm{mmol}\right)$ were added. The mixture was stirred at the same temperature for $30 \mathrm{~min}$ and, then, at room temperature for $20 \mathrm{~h}$. After the solvent had been evaporated to dryness, the residue was dissolved in EtOAc (100 $\mathrm{mL}$ ), which was washed with saturated aq. $\mathrm{NaHCO}_{3}, 0.5 \mathrm{M}$ aq. $\mathrm{KHSO}_{4}$, water, and brine (100 mL each). The organic layer was dried over anhydrous $\mathrm{Na}_{2} \mathrm{SO}_{4}$ and evaporated to dryness. The residue was purified by silica gel flash chromatography (Universal Premium L column, $\mathrm{CHCl}_{3}: \mathrm{MeOH}=99: 1-98: 2-$ $85: 15$, flow rate: $15 \mathrm{~mL} / \mathrm{min})$ to afford $\mathbf{6}(735 \mathrm{mg}, 88 \%)$ as a colorless foam.

${ }^{1} \mathrm{H}-\mathrm{NMR}\left(600 \mathrm{MHz}, \mathrm{DMSO}-d_{6}\right) \delta: 7.79$ (brs, $\left.1 \mathrm{H}, \mathrm{N} H\right), 7.66$ (brs, $\left.1 \mathrm{H}, \mathrm{NH}\right), 7.24(\mathrm{t}, 1 \mathrm{H}, J=5.6 \mathrm{~Hz}, \mathrm{~N} H)$, 7.20 (s, 1H, CONH $\left.H_{2}\right), 7.05$ (s, 1H, CONH$\left.H_{2}\right), 6.59$ (t, 2H, $\left.J=6.4 \mathrm{~Hz}, \mathrm{BocNH}\right), 6.54$ (t, 2H, $J=6.2 \mathrm{~Hz}$, BocNH), 3.52 (d, 2H, $\left.J=5.6 \mathrm{~Hz}, \mathrm{NHCH}_{2}\right), 3.26\left(\mathrm{~d}, 2 \mathrm{H}, J=5.6 \mathrm{~Hz}, \mathrm{NHCH}_{2}\right), 3.21-3.16(\mathrm{~m}, 6 \mathrm{H}), 3.00-$ 
$2.95(\mathrm{~m}, 4 \mathrm{H})\left(\mathrm{CONHCH}_{2} \mathrm{C}, \mathrm{BocNHCH}_{2}\right), 1.38$ (s, 18H, Boc), 1.38 (s, 9H, Boc), 1.36 (s, 18H, Boc); ${ }^{13} \mathrm{C}-\mathrm{NMR}\left(150 \mathrm{MHz}, \mathrm{MeOH}-d_{4}\right) \delta: 177.4,174.8,173.7(\mathrm{CO} \times 3), 158.9,158.7,158.5(\mathrm{t}-\mathrm{BuOCO} \times 5)$, $80.8,80.7,80.5,54.2,53.3,45.0,42.3,42.2,40.9,39.6,28.8,28.7$; HRMS (ESI): $m / z=[\mathrm{M}+\mathrm{Na}]^{+}$ $855.4763, \mathrm{C}_{37} \mathrm{H}_{68} \mathrm{~N}_{8} \mathrm{O}_{13} \mathrm{Na}$ requires 855.4798 .

1: To a solution of 6 (735 mg, $0.88 \mathrm{mmol})$ in dry $\mathrm{CH}_{2} \mathrm{Cl}_{2}(32 \mathrm{~mL})$, TFA $(2.0 \mathrm{~mL}, 26 \mathrm{mmol})$ was added, and the mixture was stirred at room temperature for $18 \mathrm{~h}$. The mixture was concentrated in vacuo and the residue was co-evaporated with $\mathrm{MeOH}(30 \mathrm{~mL}$, three times). The obtained colorless sticky foam was dissolved in water $(10 \mathrm{~mL}$ ) and an ion exchange column (Amberlite IRA-400J) was charged with the product to remove the TFA anion. The eluted fraction was evaporated to dryness and the residue was dried under reduced pressure to afford 1 as a colorless syrup (272 mg, 93\%).

${ }^{1} \mathrm{H}$ NMR (600 MHz, $\left.\mathrm{D}_{2} \mathrm{O}\right) \delta: 3.41$ (s, 2H, $\mathrm{CH}_{2}$ ), 3.40 (s, 2H, $\mathrm{CH}_{2}$ ), 3.25 (s, 2H, $\mathrm{H}_{2} \mathrm{NCH}_{2} \mathrm{CO}$ ), 2.72-2.65 (m, 8H, $\left.\mathrm{H}_{2} \mathrm{NCH}_{2}\right) ;{ }^{13} \mathrm{C} \mathrm{NMR}\left(150 \mathrm{MHz}, \mathrm{D}_{2} \mathrm{O}\right) \delta: 178.5,176.2,176.0,52.9,52.5,43.6,42.1,41.9,39.5$, 39.4; HRMS (ESI): $m / z=[\mathrm{M}+\mathrm{H}]^{+} 333.2360, \mathrm{C}_{12} \mathrm{H}_{29} \mathrm{~N}_{8} \mathrm{O}_{3}$ requires 333.2357.

\section{2-2. Synthesis of the $\mathrm{Ni}$ (II) complex of 1}

\section{Needle-like crystals of the $1_{14} \mathrm{Ni}_{14}$ complex $\left(\mathrm{NO}_{3}\right.$ salt)}

To a solution of $1(100 \mu \mathrm{mol})$ in $\mathrm{H}_{2} \mathrm{O}(350 \mu \mathrm{L}), \mathrm{Ni}\left(\mathrm{NO}_{3}\right)_{2} \cdot 6 \mathrm{H}_{2} \mathrm{O}(27.67 \mathrm{mg}, 95 \mu \mathrm{mol})$ in $\mathrm{H}_{2} \mathrm{O}(95 \mu \mathrm{L})$ was added. After the filtration of the mixture, the solution was concentrated by slow evaporation at room temperature. Purple needle-like crystals were obtained after 2 days (concentrated to half volume), collected, and dried in air to afford the Ni(II) complex (7.06 mg, 14\%). The yield was estimated based on presumptive molecular weight (M.W. $7211.54560\left(\mathrm{C}_{168} \mathrm{H}_{392} \mathrm{~N}_{140} \mathrm{Ni}_{14} \mathrm{O}_{126}: \mathrm{M}_{14} \mathrm{~L}_{14}\left(\mathrm{NO}_{3}\right)_{28}\right)$ because some of the counteranions could not be determined by X-ray structural analysis and other approaches. Elemental analysis: C, 27.48\%; H, 5.54\%; N, 26.80\% (Estimated: C, 27.98\%; H, 5.48\%; N, 27.19\% for $\mathbf{1}_{14} \mathrm{Ni}_{14}\left(\mathrm{NO}_{3}\right)_{28}, \mathrm{C}, 27.57 \%$, H, 5.56\%, N, 26.79\% for $\left.\mathrm{M}_{14} \mathrm{~L}_{14}\left(\mathrm{NO}_{3}\right)_{28} \cdot 6 \mathrm{H}_{2} \mathrm{O}\right)$.

Note 1: The elemental analysis suggests that most of the counteranions in the macrocycle are $\mathrm{NO}_{3}{ }^{-}$.

Note 2: We used the 0.95 equiv of $\mathrm{Ni}(\mathrm{II})$ ions in the formation of the needle-like crystals since crystalline samples were not obtained if $\mathrm{Ni}(\mathrm{II})$ ions were in excess, even in a slight amount. Therefore, a slight excess of 1 was employed. 


\section{Plate-like crystals of $1_{14} \mathrm{Ni}_{14}$ complex $\left(\mathrm{NO}_{3}\right.$ salt)}

To a solution of $1(100 \mu \mathrm{mol})$ in $\mathrm{H}_{2} \mathrm{O}(350 \mu \mathrm{L}), \mathrm{Ni}\left(\mathrm{NO}_{3}\right)_{2} \cdot 6 \mathrm{H}_{2} \mathrm{O}(27.62 \mathrm{mg}, 95 \mu \mathrm{mol})$ in $\mathrm{H}_{2} \mathrm{O}(95 \mu \mathrm{L})$ was added. After filtration with a membrane filter $(0.45 \mu \mathrm{m})$, the solution was heated to $60^{\circ} \mathrm{C}$ for $1 \mathrm{~h}$. Then, to this solution, methanol was added by slow vapor diffusion ( 1 day). The resulting powder was filtered and dried in air to obtain Ni complexes of $\mathbf{1}(21.1 \mathrm{mg})$.

The purple powder $\left(3.70 \mathrm{mg}\right.$ ) was dissolved in $\mathrm{H}_{2} \mathrm{O}(50 \mu \mathrm{L})$. Then, acetonitrile was added to the solution by vapor diffusion for 4 days at $20{ }^{\circ} \mathrm{C}$ to obtain plate-like crystals of the $\mathbf{1}_{14} \mathrm{Ni}_{14}$ complex (Figure S1). The plate-like crystals could be also obtained by the addition of methanol instead of acetonitrile.

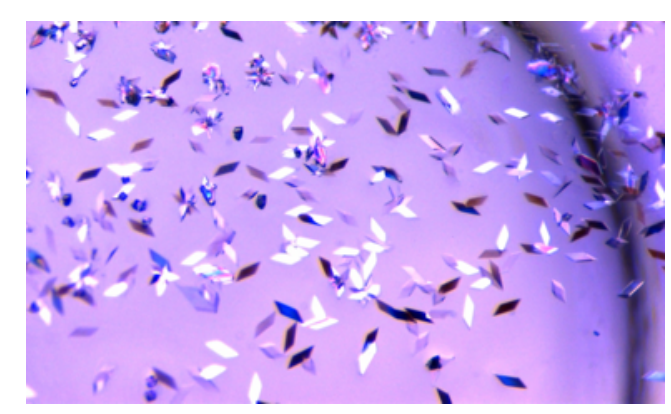

Figure S1. Microscope photograph of the plate-like crystals of $\mathbf{1}_{14} \mathrm{Ni}_{14}$ complex.

\section{Block-like crystal of $1_{12} \mathrm{Ni}_{12}$ complex ( $\mathrm{NO}_{3}$ salt)}

To a solution of $1(100 \mu \mathrm{mol})$ in $\mathrm{H}_{2} \mathrm{O}(350 \mu \mathrm{L}), \mathrm{Ni}\left(\mathrm{NO}_{3}\right)_{2} \cdot 6 \mathrm{H}_{2} \mathrm{O}(29.08 \mathrm{mg}, 100 \mu \mathrm{mol})$ in $\mathrm{H}_{2} \mathrm{O}(100 \mu \mathrm{L})$ was added. After the filtration of the mixture, acetonitrile was added to the solution by vapor diffusion for 3 days at room temperature (crystals were obtained when the mixing ratio of $\mathrm{H}_{2} \mathrm{O} / \mathrm{CH}_{3} \mathrm{CN}$ reached 0.84/1). Purple block-like and plate-like crystals were obtained as the Ni(II) complex. The crystals were collected and dried in air $(11.42 \mathrm{mg})$. As shown in Figure S2, the main crystal was assigned as the $\mathbf{1}_{12} \mathrm{Ni}_{12}$ complex; however, the existence of plate-like crystals of the $\mathbf{1}_{14} \mathrm{Ni}_{14}$ complex is still possible. Notably, the plate-like crystals of $\mathbf{1}_{14} \mathrm{Ni}_{14}$ complex could be obtained by using same protocol when a longer vapor diffusion process was used.

Note: The crystals were also obtained by mixing 1 and Ni(II)ions with a molar ratio of 1:0.95.

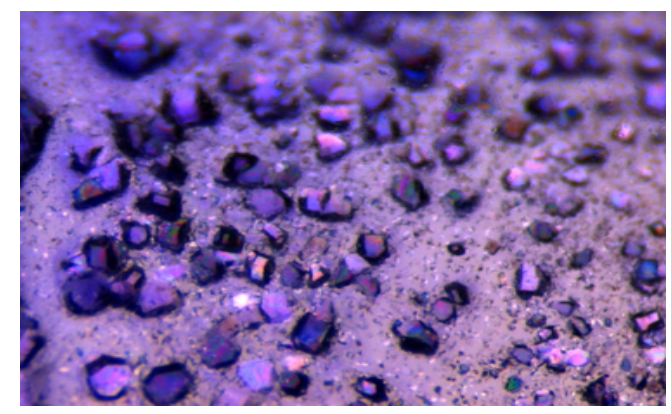

Figure S2. Microscope image of the block-like crystals of $\mathbf{1}_{12} \mathrm{Ni}_{12}$ complex. 


\section{$\left(1-3 \mathrm{H}^{+}\right)_{4} \mathrm{Ni}_{8}$ complex $\left(\mathrm{NO}_{3}\right.$ salt $)$}

To a solution of $\mathbf{1}_{14} \mathrm{Ni}_{14}$ complex (2.46 mg, $4.77 \mu \mathrm{mol}^{* 1 /} /$ unit of $\left.\mathbf{1}\right)$ in $\mathrm{H}_{2} \mathrm{O}(47.7 \mu \mathrm{L}), \mathrm{NaHCO}_{3}(1.20$ $\mathrm{mg}, 14.33 \mu \mathrm{mol})$ in $\mathrm{H}_{2} \mathrm{O}(14.33 \mu \mathrm{L})$ was added, followed by $\mathrm{Ni}\left(\mathrm{NO}_{3}\right)_{2} \cdot 6 \mathrm{H}_{2} \mathrm{O}(1.39 \mathrm{mg}, 4.77 \mu \mathrm{mol})$ in $\mathrm{H}_{2} \mathrm{O}(4.77 \mu \mathrm{L})$. After heating the mixture at $90{ }^{\circ} \mathrm{C}$ for $10 \mathrm{~min}$, the resulting solution was filtered and cooled to room temperature. Ocher (orange) needle-like crystals (Figure S3) were obtained after 1 day, collected, and dried in air to afford a Ni(II) complex $\left(0.25 \mathrm{mg}, 10 \%{ }^{* 2}\right)$.

$*^{* 1}$ : Mole number and yield were calculated assuming an anhydrous sample.

$*^{2}$ : The conversion ratio is thought to be much higher than $10 \%$. The low yield was partially caused by difficulties in the collection process.

a)

$$
1_{14} \mathrm{Ni}_{14} \text { complex }
$$

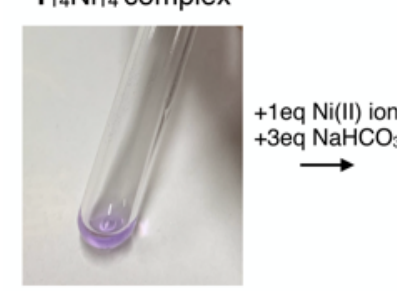

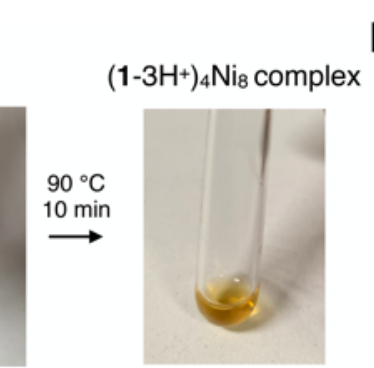

b)

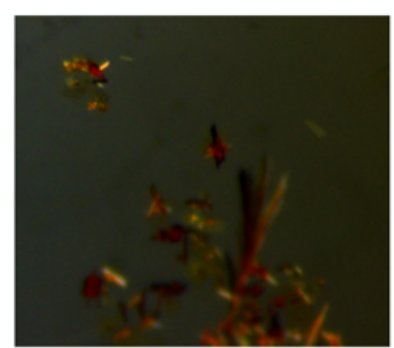

Figure S3. Color changes in the reaction mixture during the preparation of the $\left(1-3 \mathrm{H}^{+}\right)_{4} \mathrm{Ni}_{8}$ complex from the $\mathbf{1}_{14} \mathrm{Ni}_{14}$ complex (a), and a photograph of single crystals of $\left(1-3 \mathrm{H}^{+}\right)_{4} \mathrm{Ni}_{8}$ complex (b).

\section{Another synthesis method of $\left(1-3 \mathrm{H}^{+}\right)_{4} \mathrm{Ni}_{8}$ complex ( $\mathrm{NO}_{3}$ salt): direct synthesis from 1}

To a solution of $1(100 \mu \mathrm{mol})$ in $\mathrm{H}_{2} \mathrm{O}(580 \mu \mathrm{L}), \mathrm{NaHCO}_{3}(16.80 \mathrm{mg}, 200 \mu \mathrm{mol})$ in $\mathrm{H}_{2} \mathrm{O}(200 \mu \mathrm{L})$ was added, followed by $\mathrm{Ni}\left(\mathrm{NO}_{3}\right)_{2} \cdot 6 \mathrm{H}_{2} \mathrm{O}(58.25 \mathrm{mg}, 200 \mu \mathrm{mol})$ in $\mathrm{H}_{2} \mathrm{O}(400 \mu \mathrm{L})$. After the color of solution turned ocher from purple, the solution was filtered and concentrated by slow evaporation at room temperature. Ocher needle-like crystals were obtained after 2 days (concentrated to half volume), collected, and dried in air to afford a Ni(II) complex (17.03 mg, 28\%).

\section{Crystals of the trifluoromethanesulfonate (TfO) salt of the $\mathbf{1}_{14} \mathrm{Ni}_{14}$ complex}

To a solution of $1(100 \mu \mathrm{mol})$ in $\mathrm{H}_{2} \mathrm{O}(350 \mu \mathrm{L}), \mathrm{Ni}(\mathrm{TfO})_{2} \cdot 6 \mathrm{H}_{2} \mathrm{O}(35.68 \mathrm{mg}, 100 \mu \mathrm{mol})$ in $\mathrm{H}_{2} \mathrm{O}(1 \mathrm{~mL})$ was added. The solution was filtered using a membrane filter $(0.45 \mu \mathrm{m})$ and concentrated to $20 \%$ volume. The concentrated solution was stored at room temperature for 1 day. The TfO salt of the $\mathrm{Ni}(\mathrm{II})$ complex was obtained as purple plate-like crystals. 


\section{2-3. Additional information concerning the crystal structures.}

The frames were integrated using Bruker SAINT using a narrow-frame algorithm for the integration of the data. The data were corrected for absorption effects using the multi-scan method (SADABS). ${ }^{\mathrm{S} a \mathrm{a}, \mathrm{b}}$ The structures were solved and refined (on $F^{2}$ ) using Bruker SHELXTL. ${ }^{\mathrm{S} 2 \mathrm{c}}$ For the crystal data for $\mathbf{1}_{14} \mathrm{Ni}_{14}$ and $\mathbf{1}_{12} \mathrm{Ni}_{12}$ complexes, SQUEEZE ${ }^{\mathrm{S} 2 \mathrm{~d}}$ was applied because some counteranions and solvent molecules were severely disordered in the large cavities. In addition, for the data from the needle-like crystals of the $\mathbf{1}_{14} \mathrm{Ni}_{14}$ complex, all atoms were refined with SIMU and ISOR restraints because of the low resolution of the data. Because all crystals lost their crystallinity on the removal of solvent, it was not easy to obtain good data at high angles. Thus, SADI, SIMU, and ISOR restraints were applied for the counteranions ( $\mathrm{NO}_{3}$ ions or $\mathrm{TfO}^{-}$ions) and solvent of crystallization for all data except that obtained for the crystals of the $\left(1-3 \mathrm{H}^{+}\right)_{4} \mathrm{Ni}_{8}$ complex. 
Table S1. Crystal data of cyclic Ni(II) complexes of 1 as nitrate salts

$\left[\mathbf{1}_{12} \mathrm{Ni}_{12}\right]^{24+} \quad\left[\mathbf{1}_{14} \mathrm{Ni}_{14}\right]^{28+}$ (plate)

Measurement Temp $/{ }^{\circ} \mathrm{C} \quad-180$

Crystal solvent

Crystal size / mm

Crystal color

Crystal description

Formula*

$M$

Crystal system

Space group

$a / \AA$

$b / \AA$

$c / \AA$

$\alpha{ }^{\circ}$

$\beta /^{\circ}$

$V / \AA^{3}$

$Z$

$\rho_{\text {calcd }} / \mathrm{g} \cdot \mathrm{cm}^{-3}$

$F(000)$

$\mu / \mathrm{mm}^{-1}$

$\theta$ range $/^{\circ}$

GOF

Reflections collected

Independent reflections

Flack parameter

$R_{\text {int }}$

$R_{\text {sigma }}$

Final $R 1$
$(I>2 \sigma(I)$ (all data) $)$

$w R 2$

$(I>2 \sigma(I)$ (all data) $)$

CCDC No.

$\mathrm{H}_{2} \mathrm{O} / \mathrm{CH}_{3} \mathrm{OH}$

$0.30 \times 0.17 \times 0.06$

purple

block

$\mathrm{C}_{144} \mathrm{H}_{336} \mathrm{~N}_{120} \mathrm{Ni}_{12} \mathrm{O}_{210}$

7813.83

Tetragonal

$P 42 / n$

$34.334(5)$

$34.334(5)$

$19.377(3)$

90

90

90

22842.(8)

2

1.136

8112

0.577

2.07-25.03

1.331

117789

20139

0.0932

0.0670

$0.1144(0.1632)$

$0.3348(0.3748)$

1895032 $\left[1_{14} \mathrm{Ni}_{14}\right]^{28+}$ (needle)

$\left.\left(\mathbf{1}-3 \mathrm{H}^{+}\right)_{4} \mathrm{Ni} 8\right]^{4+}$
$-100$

$\mathrm{H}_{2} \mathrm{O} / \mathrm{CH}_{3} \mathrm{CN}$

$0.267 \times 0.132 \times 0.086$

purple

plate

$\mathrm{C}_{168} \mathrm{H}_{392} \mathrm{~N}_{133.5} \mathrm{Ni}_{14} \mathrm{O}_{212.4}$

8502.76

Monoclinic

$P 2{ }_{1} \mathrm{C}$

29.431(3)

$28.319(3)$

29.007(3)

114.755(3)

90

21954.(4)

2

1.286

8851

0.689

$2.16-25.03$

1.087

531593

38744

0.0690

0.0321

$0.2576(0.3099)$

1895033
$0.0924(0.1314)$

$-180 \quad-180$

$\mathrm{H}_{2} \mathrm{O}$

$0.20 \times 0.01 \times 0.005 \quad 0.06 \times 0.02 \times 0.01$

purple

needle

$\mathrm{C}_{168} \mathrm{H}_{392} \mathrm{~N}_{122} \mathrm{Ni}_{14} \mathrm{O}_{165} \quad \mathrm{C}_{48} \mathrm{H}_{142} \mathrm{~N}_{35} \mathrm{Ni}_{8} \mathrm{O}_{49}$

$7583.96 \quad 2463.64$

Triclinic Monoclinic

$P-1$

$32.429(8)$

$39.250(9)$

$42.025(10)$

$115.409(3)$

93.528(4)

$90.070(4)$

48200.(20)

4

1.046

15864

0.613

1.15-25.12

0.869

259593

168766

$\overline{0.5731}$

1.205

$0.2056(0.4584)$

$0.4114(0.5896)$

1895031 
Table S2. Supplemental data for needle-like crystals of $\left[1_{14} \mathrm{Ni}_{14}\right]^{28+}$ refined by tuning the resolution of the reflections.

$\begin{array}{lll}\text { Resolution } / \AA & 0.84 & 1.33 \\ \text { GOF } & 0.869 & 1.169 \\ \text { Reflections collected } & 259593 & 64613 \\ \text { Independent reflections } & 168959 & 34254 \\ R \text { int } & 0.5731 & 0.1993 \\ R_{\text {sigma }} & 1.2051 & 0.4243 \\ \text { Final } R 1 & 0.2056(0.4584) & 0.1514(0.2553) \\ (I>2 \sigma(I) \text { (all data) }) & & \\ w R 2 & 0.4114(0.5896) & 0.3660(0.4618) \\ (I>2 \sigma(I) \text { (all data) }) & & \end{array}$

Additional discussion of the structural data of needle crystal of $1_{14} \mathrm{Ni}_{14}$ complex.

Refinements were also performed using reflection data with a $1.33 \AA$ resolution cutoff because the R-merge and mean $I / \sigma$ in the shell between $1.43-1.33 \AA$ were $35.08 \%$ and 1.17 , respectively. The data are summarized in Table S2. The basic framework structure is the same as the structural model refined using the reflection data at $0.84 \AA$ resolution. 
Table S3 Crystal data of cyclic Ni(II) complexes of 1 as trifluoromethanesulfonate salt

$\left[\mathbf{1}_{14} \mathrm{Ni}_{14}\right]^{28+}$

Measurement Temp $/{ }^{\circ} \mathrm{C} \quad-180$

Crystal solvent $\quad \mathrm{H}_{2} \mathrm{O}$

Crystal size $/ \mathrm{mm} \quad 0.36 \times 0.25 \times 0.06$

Crystal color purple

Crystal description plate

Formula* $\quad \mathrm{C}_{175} \mathrm{H}_{391} \mathrm{~N}_{112} \mathrm{Ni}_{14} \mathrm{O}_{143} \mathrm{~S}_{7}$

M 7798.33

Crystal system Monoclinic

Space group $\quad P 2{ }_{1} / \mathrm{c}$

$a / \AA \quad 54.750(6)$

$b / \AA \quad 31.051(3)$

$c / \AA \quad 31.129(3)$

$\alpha /^{\circ} \quad 90$

$\beta /^{\circ} \quad 93.690(2)$

$\gamma /{ }^{\circ}-90$

$V / \AA^{3} \quad$ 52811.(9)

$Z$

$\rho_{\text {calcd }} / \mathrm{g} \cdot \mathrm{cm}^{-3} \quad 0.981$

$F(000) \quad 16248$

$\mu / \mathrm{mm}^{-1} \quad 0.590$

$\theta$ range $/^{\circ} \quad 0.75-25.03$

GOF $\quad 1.195$

Reflections collected 280019

Independent reflections 93149

$R_{\text {int }} \quad 0.1194$

$R_{\text {sigma }} \quad 0.1428$

Final $R 1 \quad 0.1251(0.2049)$

$(I>2 \sigma(I)$ (all data) $)$

$w R 2$

$0.3505(0.3968)$

$(I>2 \sigma(I)$ (all data) $)$

CCDC No.

1895030

*Due to the large crystalline voids, some counter anions and crystalline solvents were severely disordered. Therefore, the observed formula is shown in this table. 


\section{3-1.Additional discussion of the crystal structures of cyclic $\mathrm{Ni}$ (II) complexes of 1}

i) Plate-like crystals of the $1_{14} \mathrm{Ni}_{14}$ complex

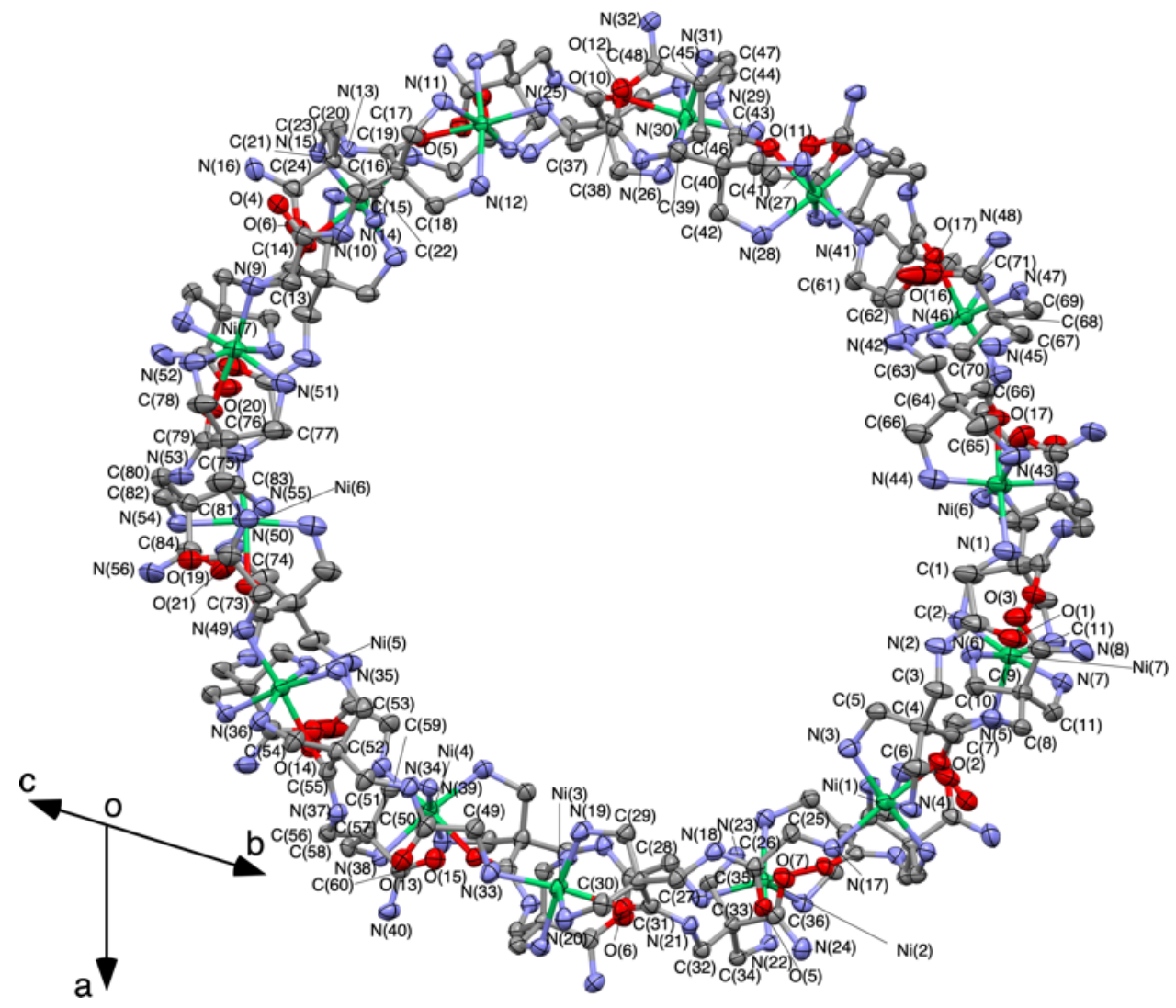

Figure S4. Molecular structure obtained from analysis of the plate-like crystals of $\left[\mathbf{1}_{14} \mathrm{Ni}_{14}\right]^{28+}$ showing $50 \%$ thermal ellipsoids. The atom numbering is shown for one of the configurations of $\mathbf{1}$. Counteranions, crystal solvent molecules, and hydrogen atoms are omitted for clarity. 


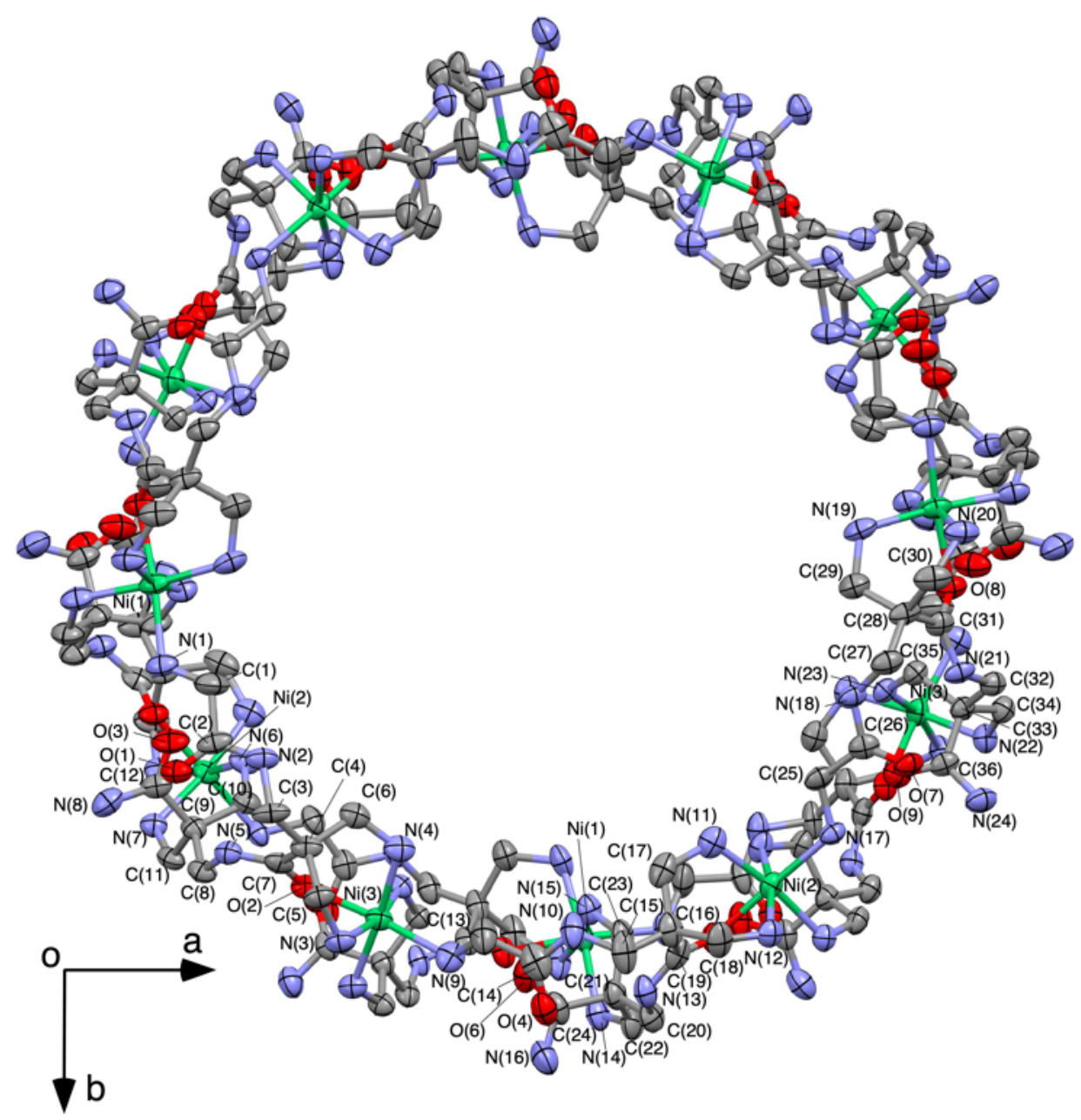

Figure S5. Molecular structure of $\left[\mathbf{1}_{12} \mathrm{Ni}_{12}\right]^{24+}$ with $50 \%$ thermal ellipsoids viewed along the $c$-axis. The atom numbers are plotted for one of the configurations of $\mathbf{1}$. Counteranions, crystal solvent molecules, and hydrogen atoms are omitted for clarity. 


\section{iii) Crystal structure of the TfO salt of $1_{14} \mathrm{Ni}_{14}$ complex}

a)
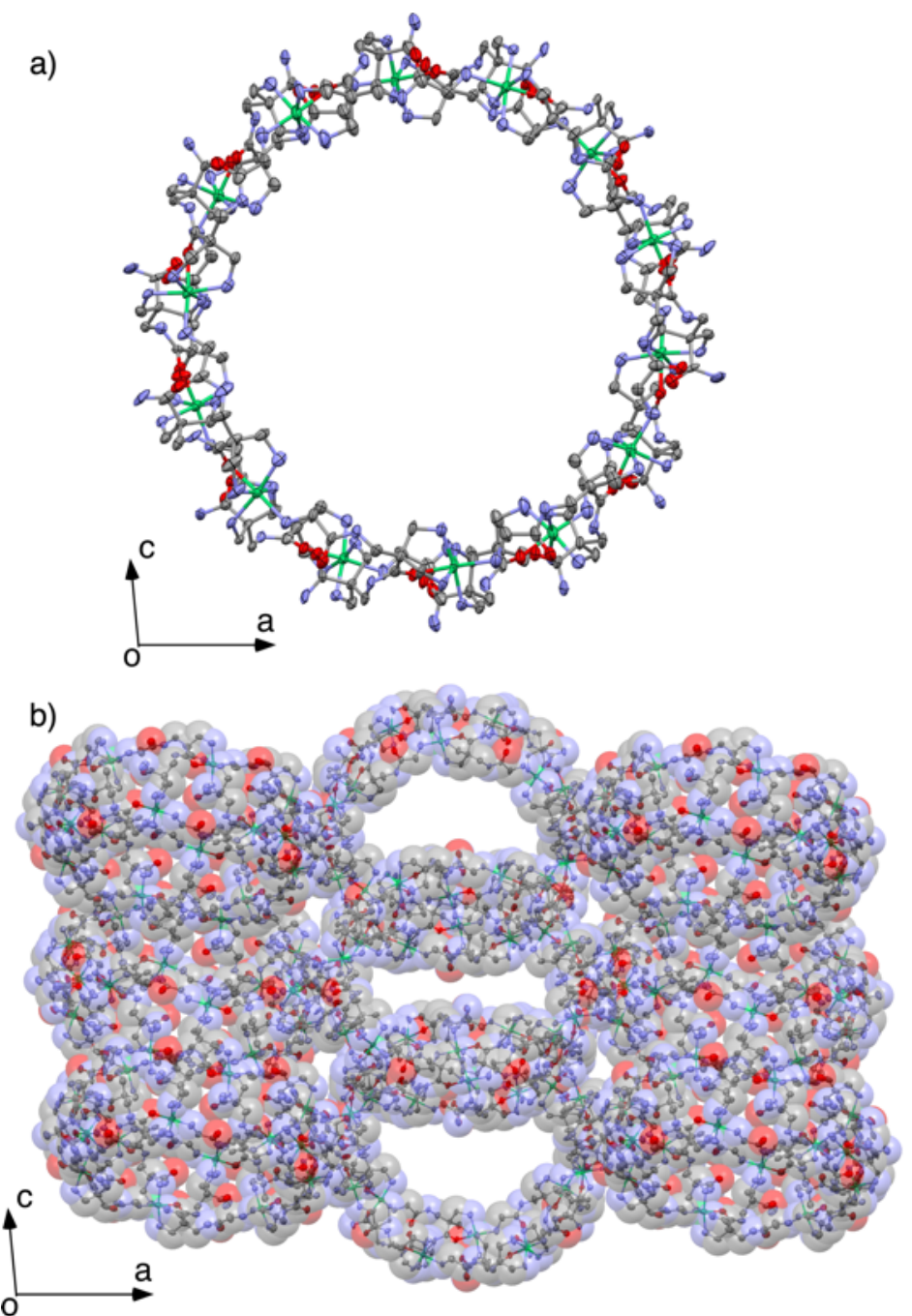

Figure S6. Cyclic structure (a) and crystal packing structure of the TfO salt of $\mathbf{1}_{14} \mathrm{Ni}_{14}$. Counteranions, crystal solvent molecules, and hydrogen atoms are omitted for clarity.

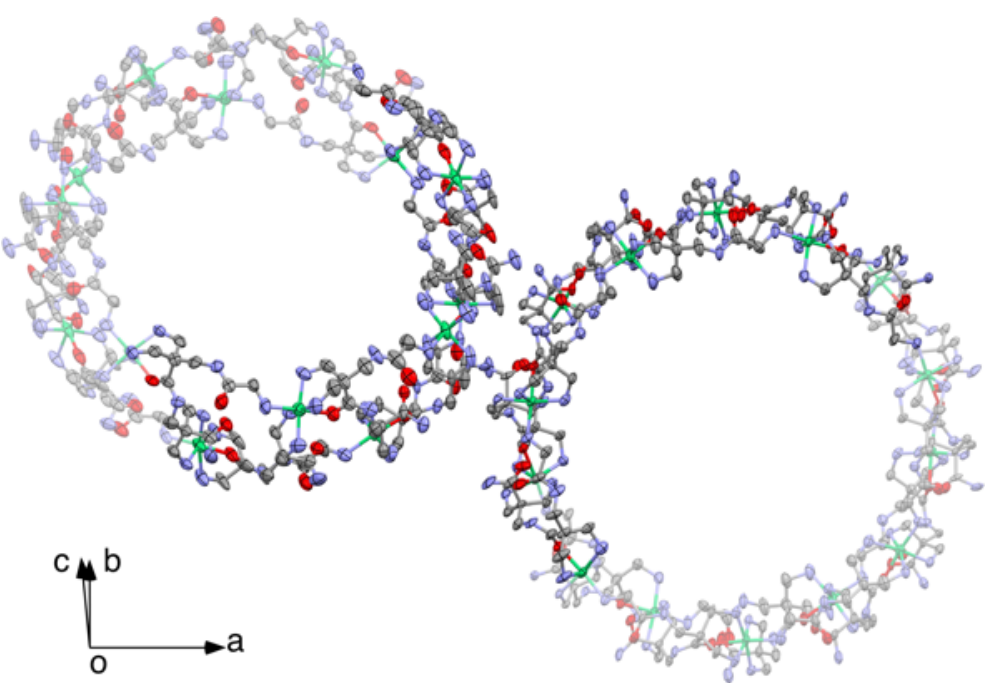

Figure S7. Asymmetric units of the TfO salt of $\mathbf{1}_{14} \mathrm{Ni}_{14}$ complex. To aid understanding, the remaining part of cyclic units are shown in 50\% transparency. Counteranions, crystal solvent molecules, and hydrogen atoms are omitted for clarity. 
a) maximum length of 1

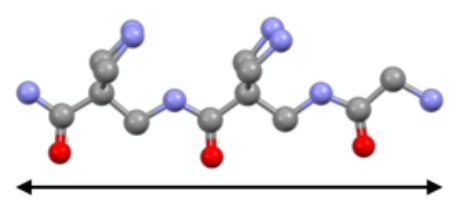

ca. $13 \AA$

b)

observed conformation of 1

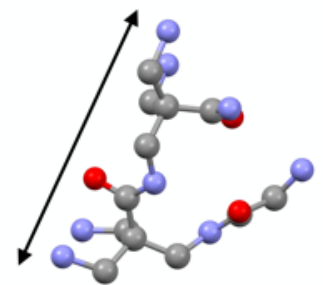

ca. $8 \AA$ c) $\quad \mathbf{1}_{14} \mathrm{Ni}_{14}$ complex

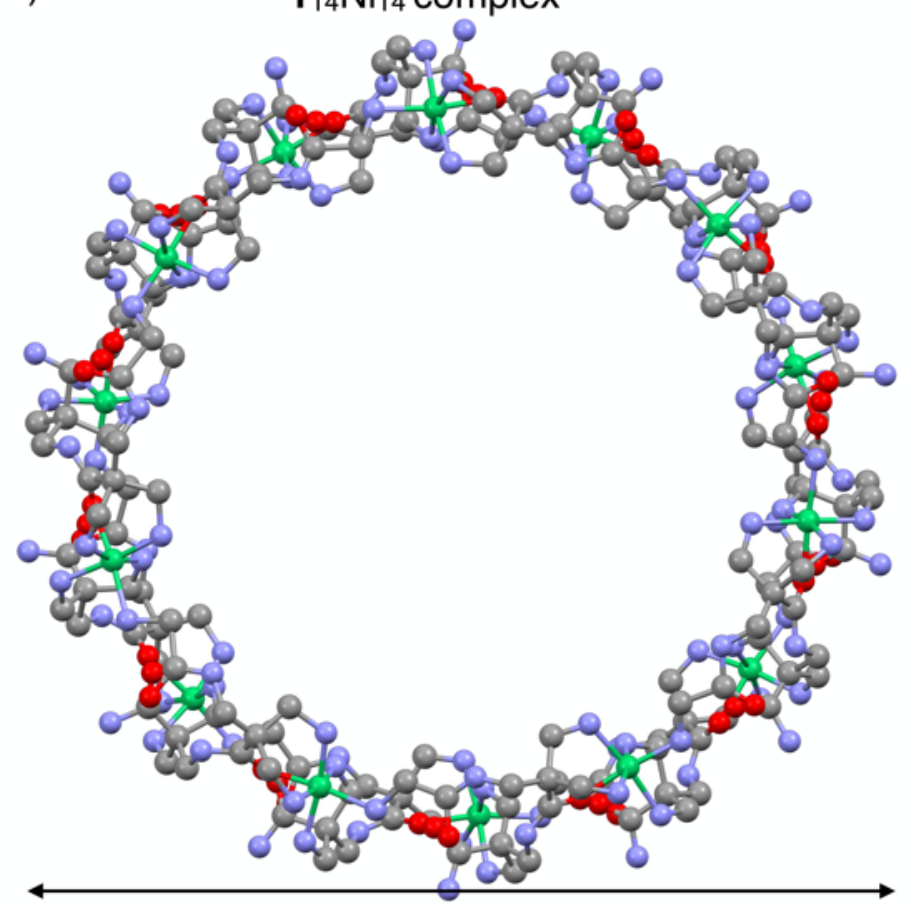

ca. $30 \AA$

Figure S8. Comparison of molecular size between linear conformation (a) and observed conformation (b) of $\mathbf{1}$ and its giant cyclic complex $\left(\mathbf{1}_{14} \mathrm{Ni}_{14}\right.$ complex) (c). Shown values were estimated distances between $\mathrm{N}$ atoms located at the both ends of the double-headed arrows.

\section{3-2. Additional discussion of the conditions required for the formation of the catenane structure}

As described in the manuscript, a catenane structure was observed in the needle-like crystals of the $\mathbf{1}_{14} \mathrm{Ni}_{14}$ complex $\left(\mathrm{NO}_{3}\right.$ salt). Despite the poor diffraction data (resolution $>1.33 \AA$ ), the formation of the catenane structure was strongly indicated by the data. The detection of corresponding peaks in the preliminary CSI mass measurements supports this result (please refer to Figure S24).

In contrast to the needle-like crystals, which were obtained by the slow condensation of an aqueous solution, the $\mathbf{1}_{14} \mathrm{Ni}_{14}$ complex does not form a catenane structure in the plate-like crystal, which was obtained from the mixture of water and organic solvent $\left(\mathrm{CH}_{3} \mathrm{CN}\right.$ or $\left.\mathrm{CH}_{3} \mathrm{OH}\right)$. Furthermore, $\mathbf{1}_{14} \mathrm{Ni}_{14}$ complex does not form catenane structure in the crystal of TfO salt in contrast to the $\mathrm{NO}_{3}$ salt. These results indicate that the existence of hydrophobic units in the solution prevent the formation of the catenane structure in the crystalline state, suggesting that the hydrophobic effect is key for the formation of the catenane structure. 


\section{3-3. Comparison of peptide conformation in giant cyclic complexes of 1}

Additional description of the peptide conformation in the various cyclic Ni(II) complexes of 1.

As described in the manuscript, the conformation of $\mathbf{1}$ alternately inverts to form the $\mathbf{1}_{14} \mathrm{Ni}_{14}$ or $\mathbf{1}_{12} \mathrm{Ni}_{12}$ complexes. In the case of the plate-like crystals of the $\mathbf{1}_{14} \mathrm{Ni}_{14}$ complex, one cyclic complex consists of seven crystallographically independent molecules (as shown in different colors in Figures S10 and S11) and their inverse conformations. For clarity, the overlaid peptide conformations in Figures S10 and S11 are shown using one conformation. There are also inverse conformations in the crystalline cyclic complexes.
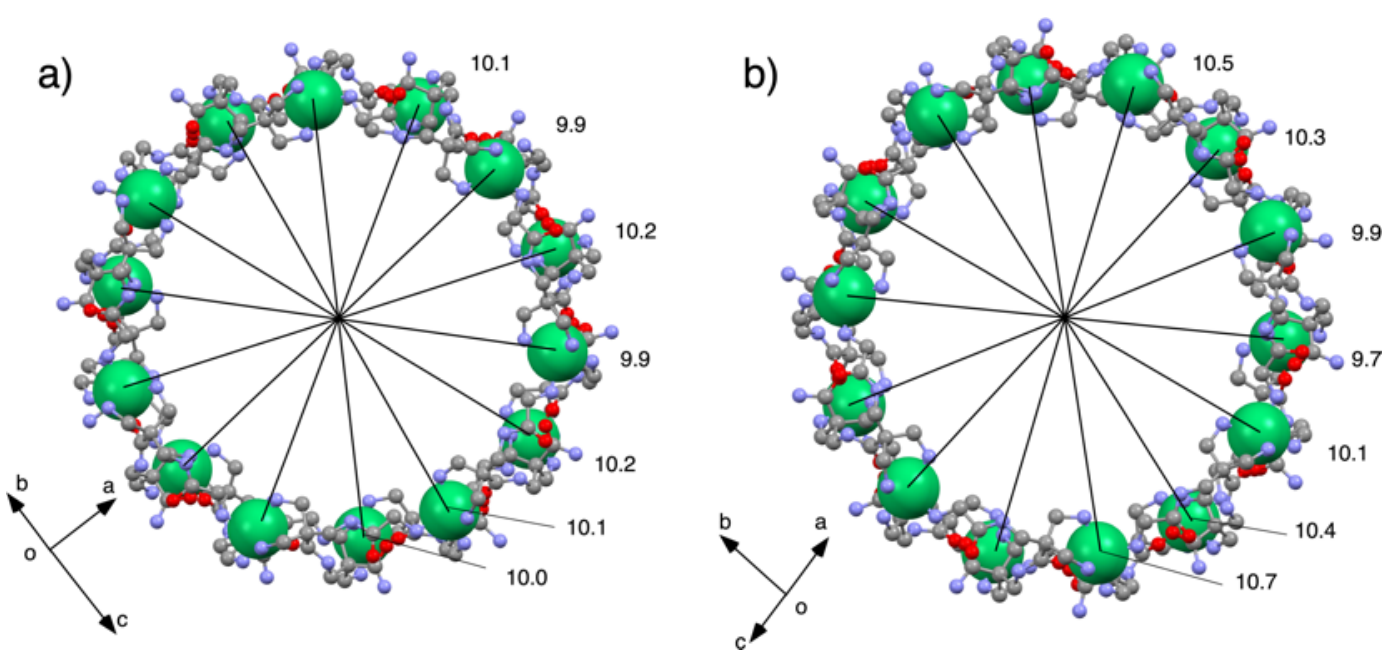

Figure S9. Comparison of the cyclic framework in the needle-like crystals (a) and plate-like crystals (b) of the $\mathbf{1}_{14} \mathrm{Ni}_{14}$ complex. The relative distances between the Ni ions are shown to aid understanding of the ellipsoidal shape of the structure of the peptide in the plate-like crystal shown in (b). 


\section{Conformation of peptides in the plate-like crystals of the $1_{14} \mathrm{Ni}_{14}$ complex}
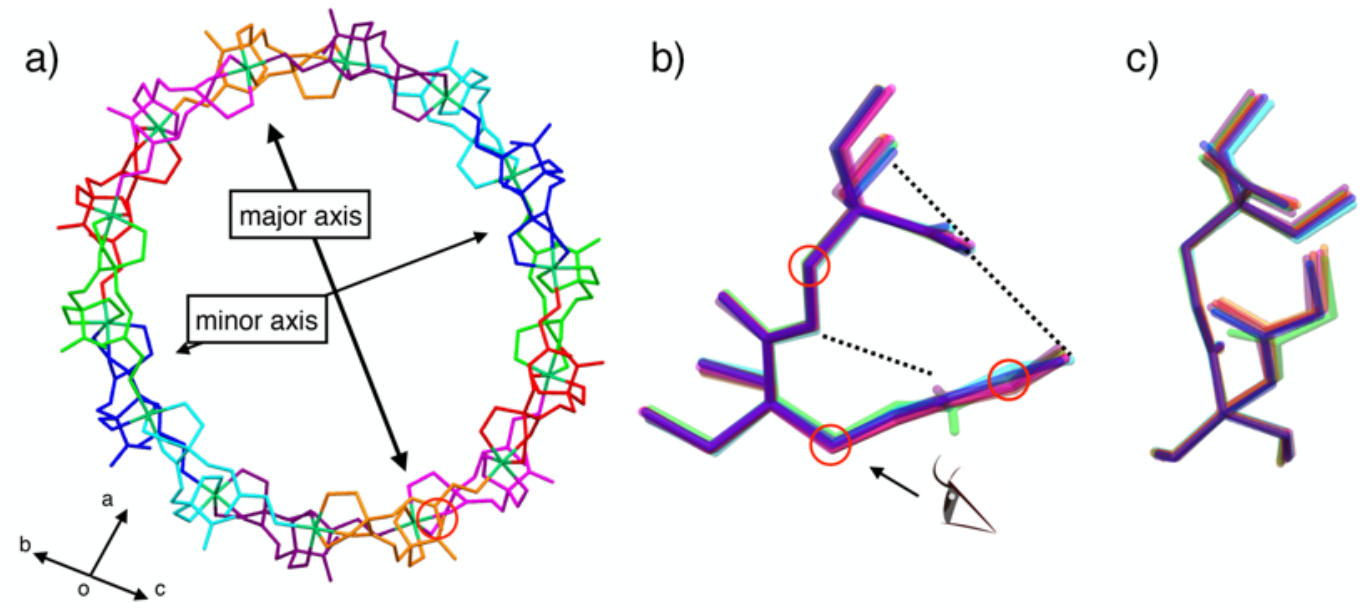

Figure S10. Cyclic structure of the $\mathbf{1}_{14} \mathrm{Ni}_{14}$ complex in the plate-like crystal showing the crystallographically independent peptides in different colors and (a) a comparison of each peptide conformation from different angle (b) and (c). The arrow in (b) represents the view angle of (c). Colors in (b) and (c) are shown with 50\% transparency.

Table S4. Distances between N and O atoms that could form hydrogen bonds in the plate-like crystals of the $\mathbf{1}_{14} \mathrm{Ni}_{14}$ complex.

\begin{tabular}{|c|c|c|c|c|c|c|}
\hline $\mathrm{N}(1)-\mathrm{O}(3)$ & $3.00(1)$ & $\mathrm{N}(5)-\mathrm{O}(1)$ & $2.949(8)$ & $\mathrm{N}(6)-\mathrm{O}(3)$ & $2.927(8)$ & pink \\
\hline $\mathrm{N}(9)-\mathrm{O}(6)$ & $2.943(6)$ & $\mathrm{N}(13)-\mathrm{O}(4)$ & $2.938(6)$ & $\mathrm{N}(14)-\mathrm{O}(6)$ & $2.962(8)$ & orange \\
\hline $\mathrm{N}(17)-\mathrm{O}(9)$ & $2.954(7)$ & $\mathrm{N}(21)-\mathrm{O}(7)$ & $2.890(6)$ & $\mathrm{N}(23)-\mathrm{O}(9)$ & $2.912(7)$ & purple \\
\hline $\mathrm{N}(25)-\mathrm{O}(12)$ & $3.079(7)$ & $\mathrm{N}(29)-\mathrm{O}(10)$ & $3.056(8)$ & $\mathrm{N}(30)-\mathrm{O}(12)$ & $3.007(9)$ & sky blue \\
\hline $\mathrm{N}(33)-\mathrm{O}(1$ & $2.991(6)$ & $\mathrm{N}(37)-\mathrm{O}(13)$ & $2.994(7)$ & $\mathrm{N}(39)-\mathrm{O}(15)$ & 2.9 & blue \\
\hline $\mathrm{N}(41)-\mathrm{O}(18$ & $2.971(9)$ & $\mathrm{N}(45)-\mathrm{O}(16)$ & $3.65(2)$ & $\mathrm{N}(46)-\mathrm{O}(18)$ & 2.911(9) & green \\
\hline $\mathrm{N}(49)-\mathrm{O}(2$ & $3.000(8)$ & $\mathrm{N}(53)-\mathrm{O}(19)$ & $2.951(7)$ & $\mathrm{N}(55)-\mathrm{O}(21)$ & $2.943(7)$ & red \\
\hline
\end{tabular}

Units/A

The large or small values relative to the others are shown in red. The colors listed in the table represent the colors of the peptides shown in Figure S10.

Table S5. Angles around the methylene groups in the peptide main chain of the plate-like crystals of the $\mathbf{1}_{14} \mathrm{Ni}_{14}$ complex.

$\begin{array}{lllllll}\mathrm{N}(1)-\mathrm{C}(1)-\mathrm{C}(2) & 116.2(8) & \mathrm{N}(2)-\mathrm{C}(3)-\mathrm{C}(4) & 114.1(6) & \mathrm{N}(5)-\mathrm{C}(8)-\mathrm{C}(9) & 114.8(5) & \text { pink } \\ \mathrm{N}(9)-\mathrm{C}(13)-\mathrm{C}(14) & 115.9(6) & \mathrm{N}(10)-\mathrm{C}(15)-\mathrm{C}(16) 114.5(5) & \mathrm{N}(13)-\mathrm{C}(20)-\mathrm{C}(21) & 115.2(5) & \text { orange } \\ \mathrm{N}(17)-\mathrm{C}(25)-\mathrm{C}(26) & 115.7(5) & \mathrm{N}(18)-\mathrm{C}(27)-\mathrm{C}(28) 117.0(5) & \mathrm{N}(21)-\mathrm{C}(32)-\mathrm{C}(33) & 114.3(5) & \text { purple } \\ \mathrm{N}(25)-\mathrm{C}(37)-\mathrm{C}(38) & 113.1(5) & \mathrm{N}(26)-\mathrm{C}(39)-\mathrm{C}(40) 113.5(5) & \mathrm{N}(29)-\mathrm{C}(44)-\mathrm{C}(45) & 115.2(5) & \text { sky blue } \\ \mathrm{N}(33)-\mathrm{C}(49)-\mathrm{C}(50) & 113.6(6) & \mathrm{N}(34)-\mathrm{C}(51)-\mathrm{C}(52) 114.2(6) & \mathrm{N}(37)-\mathrm{C}(56)-\mathrm{C}(57) & 113.9(5) & \text { blue } \\ \mathrm{N}(41)-\mathrm{C}(61)-\mathrm{C}(62) & 113.3(6) & \mathrm{N}(42)-\mathrm{C}(63)-\mathrm{C}(64) 112.4(6) & \mathrm{N}(45)-\mathrm{C}(68)-\mathrm{C}(69) & 115.3(6) & \text { green } \\ \mathrm{N}(49)-\mathrm{C}(73)-\mathrm{C}(74) & 114.6(7) & \mathrm{N}(50)-\mathrm{C}(75)-\mathrm{C}(76) 115.5(7) & \mathrm{N}(53)-\mathrm{C}(80)-\mathrm{C}(81) & 114.5(6) & \text { red }\end{array}$

Units/ ${ }^{\circ}$

The large or small values relative to the others are shown in red. The colors listed in the table represent the colors of the peptides shown in Figure S10. 
Table S6. Torsion angles around the methylene groups in the peptide main chain of the plate-like crystals of the $\mathbf{1}_{14} \mathrm{Ni}_{14}$ complex.

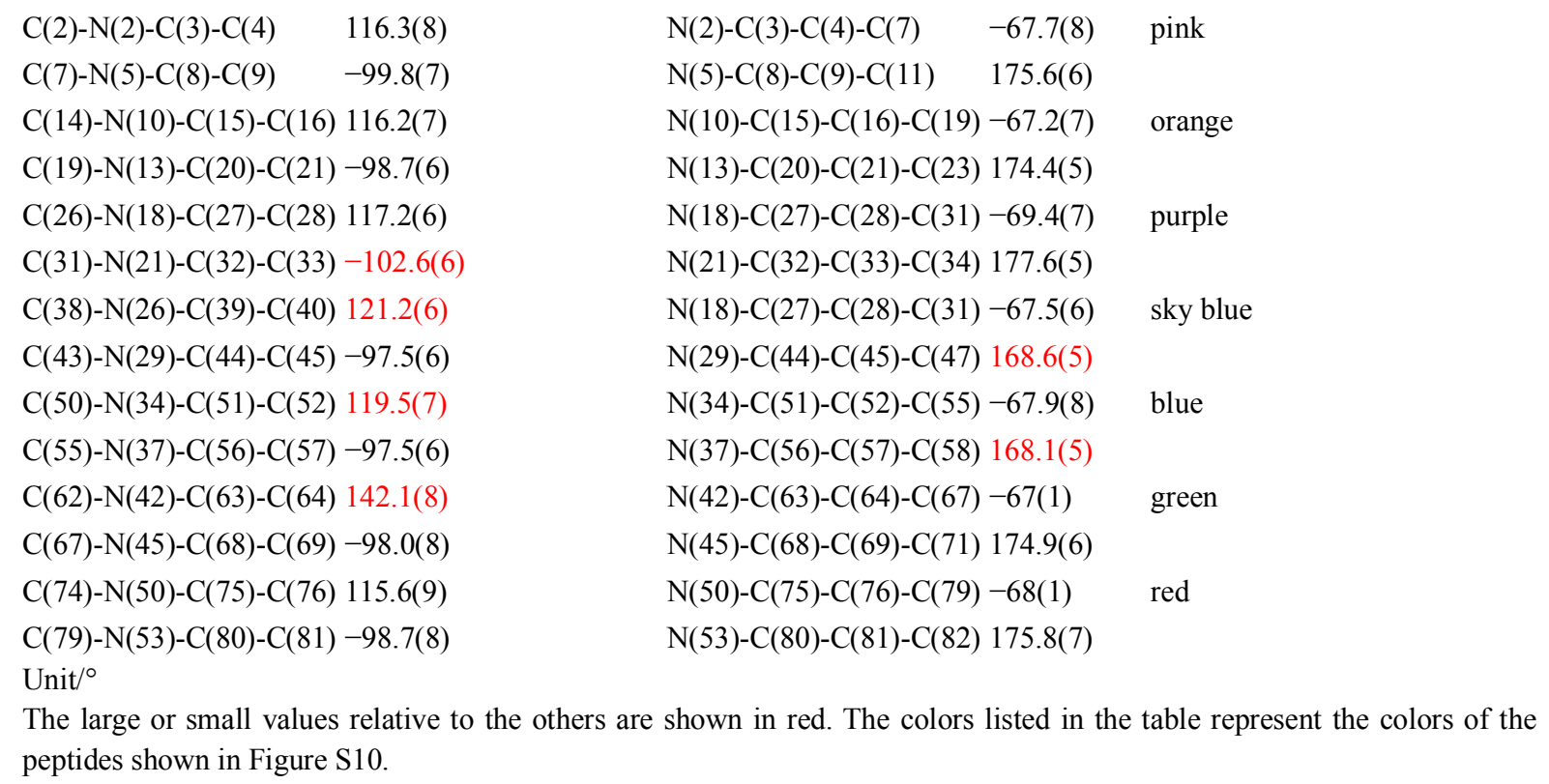

\section{Comparison of each $\mathrm{Ni}(\mathrm{II})$ center in the plate-like crystals of the $1_{14} \mathrm{Ni}_{14}$ complex}

Table S7. Bond lengths around each Ni(II) center in the plate-like crystals of $\mathbf{1}_{14} \mathrm{Ni}_{14}$ complex.

\begin{tabular}{|c|c|c|c|c|c|}
\hline $\mathrm{Ni}(1)-\mathrm{N}(3)$ & $2.122(5)$ & $\mathrm{Ni}(1)-\mathrm{N}(4)$ & $2.139(5)$ & $\mathrm{Ni}(1)-\mathrm{N}(14)$ & $2.100(5)$ \\
\hline $\mathrm{Ni}(1)-\mathrm{N}(15)$ & $2.098(5)$ & $\mathrm{Ni}(1)-\mathrm{N}(17)$ & $2.127(5)$ & $\mathrm{Ni}(1)-\mathrm{O}(2)$ & $2.081(4)$ \\
\hline $\mathrm{Ni}(2)-\mathrm{N}(11)$ & $2.125(5)$ & $\mathrm{Ni}(2)-\mathrm{N}(12)$ & $2.106(5)$ & $\mathrm{Ni}(2)-\mathrm{N}(22)$ & $2.120(5)$ \\
\hline $\mathrm{Ni}(2)-\mathrm{N}(23)$ & $2.094(5)$ & $\mathrm{Ni}(2)-\mathrm{N}(25)$ & $2.127(5)$ & $\mathrm{Ni}(2)-\mathrm{O}(5)$ & $2.099(4)$ \\
\hline $\mathrm{Ni}(3)-\mathrm{N}(19)$ & $2.107(6)$ & $\mathrm{Ni}(3)-\mathrm{N}(20)$ & $2.117(5)$ & $\mathrm{Ni}(3)-\mathrm{N}(30)$ & $2.084(5)$ \\
\hline $\mathrm{Ni}(3)-\mathrm{N}(31)$ & $2.104(5)$ & $\mathrm{Ni}(3)-\mathrm{N}(33)$ & $2.141(5)$ & $\mathrm{Ni}(3)-\mathrm{O}(8)$ & $2.086(4)$ \\
\hline $\mathrm{Ni}(4)-\mathrm{N}(27)$ & $2.125(6)$ & $\mathrm{Ni}(4)-\mathrm{N}(28)$ & $2.096(5)$ & $\mathrm{Ni}(4)-\mathrm{N}(38)$ & $2.116(5)$ \\
\hline $\mathrm{Ni}(4)-\mathrm{N}(39)$ & $2.077(5)$ & $\mathrm{Ni}(4)-\mathrm{N}(41)$ & $2.108(5)$ & $\mathrm{Ni}(4)-\mathrm{O}(11)$ & $2.092(4)$ \\
\hline $\mathrm{Ni}(5)-\mathrm{N}(35)$ & $2.109(6)$ & $\mathrm{Ni}(5)-\mathrm{N}(36)$ & $2.116(6)$ & $\mathrm{Ni}(5)-\mathrm{N}(46)$ & $2.074(6)$ \\
\hline $\mathrm{Ni}(5)-\mathrm{N}(47)$ & $2.116(6)$ & $\mathrm{Ni}(5)-\mathrm{N}(49)$ & $2.124(6)$ & $\mathrm{Ni}(5)-\mathrm{O}(14)$ & $2.093(4)$ \\
\hline $\mathrm{Ni}(6)-\mathrm{N}(1)$ & $2.141(6)$ & $\mathrm{Ni}(6)-\mathrm{N}(43)$ & $2.136(6)$ & $\mathrm{Ni}(6)-\mathrm{N}(44)$ & $2.114(7)$ \\
\hline $\mathrm{Ni}(6)-\mathrm{N}(54)$ & $2.111(7)$ & $\mathrm{Ni}(6)-\mathrm{N}(55)$ & $2.089(6)$ & $\mathrm{Ni}(6)-\mathrm{O}(17)$ & $2.095(4)$ \\
\hline $\mathrm{Ni}(7)-\mathrm{N}(6)$ & $2.092(6)$ & $\mathrm{Ni}(7)-\mathrm{N}(7)$ & $2.122(7)$ & $\mathrm{Ni}(7)-\mathrm{N}(9)$ & $2.135(6)$ \\
\hline $\mathrm{Ni}(7)-\mathrm{N}(51)$ & $2.122(6)$ & $\mathrm{Ni}(7)-\mathrm{N}(52)$ & $2.115(7)$ & $\mathrm{Ni}(7)-\mathrm{O}(20)$ & $2.082(5)$ \\
\hline
\end{tabular}


Table S8. Bond angles of each $\mathrm{Ni}(\mathrm{II})$ center in the plate-like crystals of the $\mathbf{1}_{14} \mathrm{Ni}_{14}$ complex.

\begin{tabular}{|c|c|c|c|c|c|c|c|}
\hline $\mathrm{N}(3)-\mathrm{Ni}(1)-\mathrm{N}(4)$ & $85.4(2)$ & $\mathrm{N}(3)-\mathrm{Ni}(1)-\mathrm{N}(14)$ & $92.2(2)$ & $\mathrm{N}(3)-\mathrm{Ni}(1)-\mathrm{N}(17)$ & $95.0(2)$ & $\mathrm{N}(4)-\mathrm{Ni}(1)-\mathrm{N}(15)$ & $91.6(2)$ \\
\hline $\mathrm{N}(4)-\mathrm{Ni}(1)-\mathrm{N}(17)$ & $95.3(2)$ & $\mathrm{N}(14)-\mathrm{Ni}(1)-\mathrm{N}(15)$ & $89.5(2)$ & $\mathrm{N}(14)-\mathrm{Ni}(1)-\mathrm{N}(17)$ & $96.8(2)$ & $\mathrm{N}(15)-\mathrm{Ni}(1)-\mathrm{N}(17)$ & $91.0(2)$ \\
\hline $\mathrm{N}(3)-\mathrm{Ni}(1)-\mathrm{O}(2)$ & $88.8(2)$ & $\mathrm{N}(4)-\mathrm{Ni}(1)-\mathrm{O}(2)$ & $82.9(2)$ & $\mathrm{N}(14)-\mathrm{Ni}(1)-\mathrm{O}(2)$ & $85.2(2)$ & $\mathrm{N}(15)-\mathrm{Ni}(1)-\mathrm{O}(2)$ & $85.1(2)$ \\
\hline $\mathrm{N}(11)-\mathrm{Ni}(2)-\mathrm{N}(12)$ & $86.0(2)$ & $\mathrm{N}(11)-\mathrm{Ni}(2)-\mathrm{N}(22)$ & $88.3(2)$ & $\mathrm{N}(11)-\mathrm{Ni}(2)-\mathrm{N}(25)$ & $96.6(2)$ & $\mathrm{N}(12)-\mathrm{Ni}(2)-\mathrm{N}(23)$ & $93.7(2)$ \\
\hline $\mathrm{N}(12)-\mathrm{Ni}(2)-\mathrm{N}(25)$ & $94.8(2)$ & $\mathrm{N}(22)-\mathrm{Ni}(2)-\mathrm{N}(23)$ & $90.9(2)$ & $\mathrm{N}(22)-\mathrm{Ni}(2)-\mathrm{N}(25)$ & $90.9(2)$ & $\mathrm{N}(23)-\mathrm{Ni}(2)-\mathrm{N}(25)$ & $94.5(2)$ \\
\hline $\mathrm{N}(11)-\mathrm{Ni}(2)-\mathrm{O}(5)$ & $82.5(2)$ & $\mathrm{N}(12)-\mathrm{Ni}(2)-\mathrm{O}(5)$ & $88.3(2)$ & $\mathrm{N}(22)-\mathrm{Ni}(2)-\mathrm{O}(5)$ & $86.0(2)$ & $\mathrm{N}(23)-\mathrm{Ni}(2)-\mathrm{O}(5)$ & $86.4(2)$ \\
\hline $\mathrm{N}(19)-\mathrm{Ni}(3)-\mathrm{N}(20)$ & $85.3(2)$ & $\mathrm{N}(19)-\mathrm{Ni}(3)-\mathrm{N}(30)$ & $91.5(2)$ & $\mathrm{N}(19)-\mathrm{Ni}(3)-\mathrm{N}(33)$ & $95.2(2)$ & $\mathrm{N}(20)-\mathrm{Ni}(3)-\mathrm{N}(31)$ & $91.5(2)$ \\
\hline $\mathrm{N}(20)-\mathrm{Ni}(3)-\mathrm{N}(33)$ & $94.5(2)$ & $\mathrm{N}(30)-\mathrm{Ni}(3)-\mathrm{N}(31)$ & $90.8(2)$ & $\mathrm{N}(30)-\mathrm{Ni}(3)-\mathrm{N}(33)$ & $97.9(2)$ & $\mathrm{N}(31)-\mathrm{Ni}(3)-\mathrm{N}(33)$ & $89.2(2)$ \\
\hline $\mathrm{N}(19)-\mathrm{Ni}(3)-\mathrm{O}(8)$ & $88.7(2)$ & $\mathrm{N}(20)-\mathrm{Ni}(3)-\mathrm{O}(8)$ & $82.9(2)$ & $\mathrm{N}(30)-\mathrm{Ni}(3)-\mathrm{O}(8)$ & $84.9(2)$ & $\mathrm{N}(31)-\mathrm{Ni}(3)-\mathrm{O}(8)$ & $86.7(2)$ \\
\hline $\mathrm{N}(27)-\mathrm{Ni}(4)-\mathrm{N}(28)$ & $85.6(2)$ & $\mathrm{N}(27)-\mathrm{Ni}(4)-\mathrm{N}(38)$ & $90.8(2)$ & $\mathrm{N}(27)-\mathrm{Ni}(4)-\mathrm{N}(41)$ & $94.0(2)$ & $\mathrm{N}(28)-\mathrm{Ni}(4)-\mathrm{N}(39)$ & $91.3(2)$ \\
\hline $\mathrm{N}(28)-\mathrm{Ni}(4)-\mathrm{N}(41)$ & $95.5(2)$ & $\mathrm{N}(38)-\mathrm{Ni}(4)-\mathrm{N}(39)$ & $91.3(2)$ & $\mathrm{N}(38)-\mathrm{Ni}(4)-\mathrm{N}(41)$ & $89.3(2)$ & $\mathrm{N}(39)-\mathrm{Ni}(4)-\mathrm{N}(41)$ & $97.1(2)$ \\
\hline $\mathrm{N}(27)-\mathrm{Ni}(4)-\mathrm{O}(11)$ & $82.7(2)$ & $\mathrm{N}(28)-\mathrm{Ni}(4)-\mathrm{O}(11)$ & $88.8(2)$ & $\mathrm{N}(38)-\mathrm{Ni}(4)-\mathrm{O}(11)$ & $86.2(2)$ & $\mathrm{N}(39)-\mathrm{Ni}(4)-\mathrm{O}(11)$ & $86.4(2)$ \\
\hline $\mathrm{N}(35)-\mathrm{Ni}(5)-\mathrm{N}(36)$ & $86.1(2)$ & $\mathrm{N}(35)-\mathrm{Ni}(5)-\mathrm{N}(46)$ & $91.8(2)$ & $\mathrm{N}(35)-\mathrm{Ni}(5)-\mathrm{N}(49)$ & $96.5(2)$ & $\mathrm{N}(36)-\mathrm{Ni}(5)-\mathrm{N}(49)$ & $94.8(2)$ \\
\hline $\mathrm{N}(36)-\mathrm{Ni}(5)-\mathrm{N}(47)$ & $89.8(2)$ & $\mathrm{N}(46)-\mathrm{Ni}(5)-\mathrm{N}(47)$ & $91.2(2)$ & $\mathrm{N}(46)-\mathrm{Ni}(5)-\mathrm{N}(49)$ & $95.6(2)$ & $\mathrm{N}(47)-\mathrm{Ni}(5)-\mathrm{N}(49)$ & $89.7(2)$ \\
\hline $\mathrm{N}(35)-\mathrm{Ni}(5)-\mathrm{O}(14)$ & $88.0(2)$ & $\mathrm{N}(36)-\mathrm{Ni}(5)-\mathrm{O}(14)$ & $83.2(2)$ & $\mathrm{N}(46)-\mathrm{Ni}(5)-\mathrm{O}(14)$ & $86.6(2)$ & $\mathrm{N}(47)-\mathrm{Ni}(5)-\mathrm{O}(14)$ & $85.6(2)$ \\
\hline $\mathrm{N}(1)^{\# 1}-\mathrm{Ni}(6)-\mathrm{N}(43)$ & $95.6(2)$ & $\mathrm{N}(1)^{\# 1}-\mathrm{Ni}(6)-\mathrm{N}(44)$ & $94.8(2)$ & $\mathrm{N}(1)^{\# 1}-\mathrm{Ni}(6)-\mathrm{N}(54)$ & $91.4(2)$ & $\mathrm{N}(1)^{\# 1}-\mathrm{Ni}(6)-\mathrm{N}(55)$ & $95.9(2)$ \\
\hline $\mathrm{N}(43)-\mathrm{Ni}(6)-\mathrm{N}(44)$ & $84.5(3)$ & $\mathrm{N}(43)-\mathrm{Ni}(6)-\mathrm{N}(54)$ & $92.0(3)$ & $\mathrm{N}(44)-\mathrm{Ni}(6)-\mathrm{N}(55)$ & $92.5(3)$ & $\mathrm{N}(54)-\mathrm{Ni}(6)-\mathrm{N}(55)$ & $89.8(2)$ \\
\hline $\mathrm{N}(43)-\mathrm{Ni}(6)-\mathrm{O}(17)$ & $82.9(2)$ & $\mathrm{N}(44)-\mathrm{Ni}(6)-\mathrm{O}(17)$ & $88.5(3)$ & $\mathrm{N}(54)-\mathrm{Ni}(6)-\mathrm{O}(17)$ & $85.3(2)$ & $\mathrm{N}(55)-\mathrm{Ni}(6)-\mathrm{O}(17)$ & $85.7(2)$ \\
\hline $\mathrm{N}(6)^{\# 1}-\mathrm{Ni}(7)-\mathrm{N}(7)^{\# 1}$ & $88.9(2)$ & $\mathrm{N}(6)^{\# 1}-\mathrm{Ni}(7)-\mathrm{N}(9)^{\# 1}$ & $97.9(2)$ & $\mathrm{N}(6)^{\# 1}-\mathrm{Ni}(7)-\mathrm{N}(51)$ & $91.3(3)$ & $\mathrm{N}(7)^{\# 1}-\mathrm{Ni}(7)-\mathrm{N}(9)^{\# 1}$ & $90.5(2)$ \\
\hline $\mathrm{N}(7)^{\# 1}-\mathrm{Ni}(7)-\mathrm{N}(52)$ & $92.5(2)$ & $\mathrm{N}(9)^{\# 1}-\mathrm{Ni}(7)-\mathrm{N}(51)$ & $96.1(2)$ & $\mathrm{N}(9)^{\# 1}-\mathrm{Ni}(7)-\mathrm{N}(52)$ & $94.4(3)$ & $\mathrm{N}(51)-\mathrm{Ni}(7)-\mathrm{N}(52)$ & $85.9(3)$ \\
\hline $\mathrm{N}(6)^{\# 1}-\mathrm{Ni}(7)-\mathrm{O}(20)$ & $86.0(2)$ & $\mathrm{N}(7)^{\# 1}-\mathrm{Ni}(7)-\mathrm{O}(20)$ & $85.9(2)$ & $\mathrm{N}(51)-\mathrm{Ni}(7)-\mathrm{O}(20)$ & $87.5(2)$ & $\mathrm{N}(52)-\mathrm{Ni}(7)-\mathrm{O}(20)$ & $81.8(2)$ \\
\hline
\end{tabular}




\section{Conformation of the peptides in the block-like crystals of the $1_{12} \mathrm{Ni}_{12}$ complex}
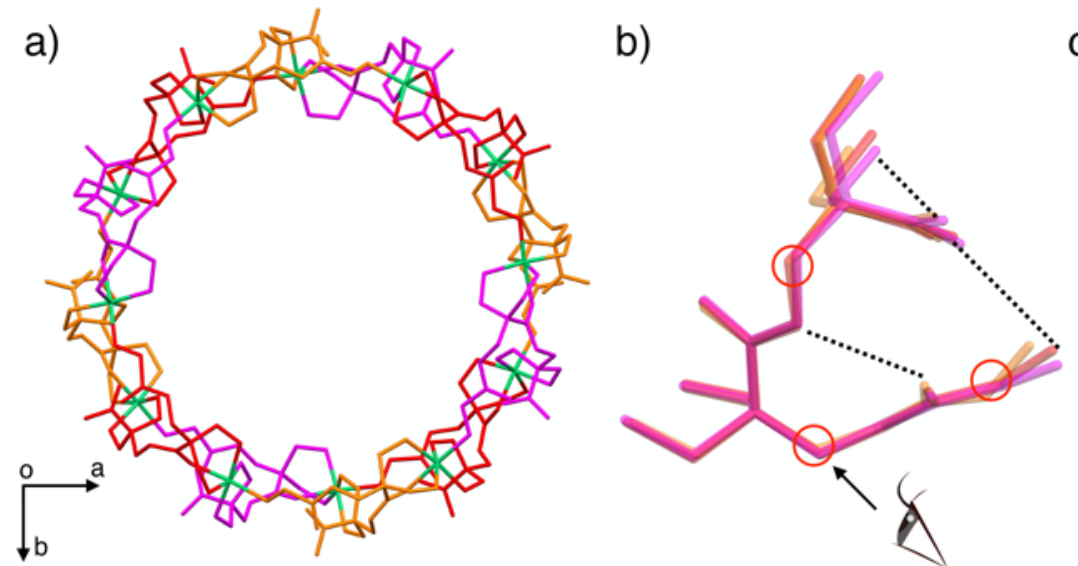

c)

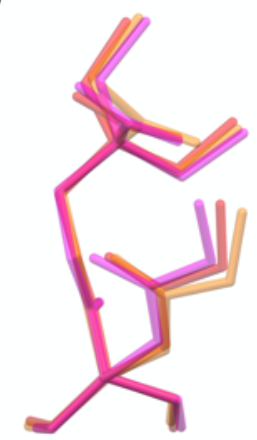

Figure S11. Cyclic structure of the $\mathbf{1}_{12} \mathrm{Ni}_{12}$ complex showing the crystallographically independent peptides in different colors and (a) a comparison of each peptide conformation from different angles (b) and (c). The arrow in (b) represents the viewing angle in (c). Colors in (b) and (c) are shown at 50\% transparency.

Table S9. Distances between $\mathrm{N}$ and $\mathrm{O}$ atoms that could form hydrogen bonds in the plate-like crystals of the $\mathbf{1}_{12} \mathrm{Ni}_{12}$ complex.
$\mathrm{N}(1)-\mathrm{O}(3) \quad 3.036(8)$
$\mathrm{N}(5)-\mathrm{O}(1) \quad 2.857(8)$
$\mathrm{N}(9)-\mathrm{O}(6) \quad 2.963(8)$
$\mathrm{N}(13)-\mathrm{O}(4) \quad 2.910(8)$
$\mathrm{N}(6)-\mathrm{O}(3) \quad 2.901(8) \quad$ red
$\mathrm{N}(17)-\mathrm{O}(9) \quad 3.041(8)$
$\mathrm{N}(21)-\mathrm{O}(7) \quad 2.957(7)$
$\mathrm{N}(15)-\mathrm{O}(6) \quad 2.922(8) \quad$ purple
$\mathrm{N}(23)-\mathrm{O}(9) \quad 2.928(8) \quad$ orange

Units/A

The colors shown in the table represents the colors of the peptides shown in Figure S11.

Table S10. Bond angles around the methylene groups in the peptide main chain of block crystal of $\mathbf{1}_{12} \mathrm{Ni}_{12}$ complex.

$\begin{array}{lllllll}\mathrm{N}(1)-\mathrm{C}(1)-\mathrm{C}(2) & 115.8(7) & \mathrm{N}(2)-\mathrm{C}(3)-\mathrm{C}(4) & 114.2(6) & \mathrm{N}(5)-\mathrm{C}(8)-\mathrm{C}(9) & 113.7(5) & \text { red } \\ \mathrm{N}(9)-\mathrm{C}(13)-\mathrm{C}(14) & 116.5(7) & \mathrm{N}(10)-\mathrm{C}(15)-\mathrm{C}(16) & 112.5(7) & \mathrm{N}(13)-\mathrm{C}(20)-\mathrm{C}(21) & 114.7(7) & \text { purple } \\ \mathrm{N}(17)-\mathrm{C}(25)-\mathrm{C}(26) & 114.2(6) & \mathrm{N}(18)-\mathrm{C}(27)-\mathrm{C}(28) & 114.3(6) & \mathrm{N}(21)-\mathrm{C}(32)-\mathrm{C}(33) & 113.9(6) & \text { orange }\end{array}$

Unit $/^{\circ}$

The colors shown in the table represent the colors of the peptides shown in Figure S11.

Table S11. Torsion angles between methylene groups in the peptide main chain of block-like crystals of the $\mathbf{1}_{12} \mathrm{Ni}_{12}$ complex.

$\begin{array}{lllll}\mathrm{C}(2)-\mathrm{N}(2)-\mathrm{C}(3)-\mathrm{C}(4) & -114.3(8) & \mathrm{N}(2)-\mathrm{C}(3)-\mathrm{C}(4)-\mathrm{C}(7) & 72.0(8) & \text { red } \\ \mathrm{C}(7)-\mathrm{N}(5)-\mathrm{C}(8)-\mathrm{C}(9) & 102.8(7) & \mathrm{N}(5)-\mathrm{C}(8)-\mathrm{C}(9)-\mathrm{C}(11) & -175.1(6) & \\ \mathrm{C}(14)-\mathrm{N}(10)-\mathrm{C}(15)-\mathrm{C}(16)-117.8(9) & \mathrm{N}(10)-\mathrm{C}(15)-\mathrm{C}(16)-\mathrm{C}(19) 78.5(9) & \text { purple } \\ \mathrm{C}(19)-\mathrm{N}(13)-\mathrm{C}(20)-\mathrm{C}(21) 98.5(8) & \mathrm{N}(13)-\mathrm{C}(20)-\mathrm{C}(21)-\mathrm{C}(22)-174.2(6) & \\ \mathrm{C}(26)-\mathrm{N}(18)-\mathrm{C}(27)-\mathrm{C}(28)-116.9(7) & \mathrm{N}(18)-\mathrm{C}(27)-\mathrm{C}(28)-\mathrm{C}(31) 67.8(8) & \text { orange } \\ \mathrm{C}(31)-\mathrm{N}(21)-\mathrm{C}(32)-\mathrm{C}(33) 97.6(7) & \mathrm{N}(21)-\mathrm{C}(32)-\mathrm{C}(33)-\mathrm{C}(34)-172.7(5) & \end{array}$

Unit/ ${ }^{\circ}$

The large or small values relative to the others are shown in red. The colors listed in the table represent the colors of the peptides shown in Figure S11. 
Comparison of each $\mathrm{Ni}(\mathrm{II})$ center in the block-like crystals of the $\mathbf{1}_{12} \mathrm{Ni}_{12}$ complex

Table S12. Distances of coordination bonds to the $\mathrm{Ni}(\mathrm{II})$ center in the block-like crystals of the $\mathbf{1}_{12} \mathrm{Ni}_{12}$ complex.

$\mathrm{Ni}(1)-\mathrm{O}(8) \quad 2.107(5)$

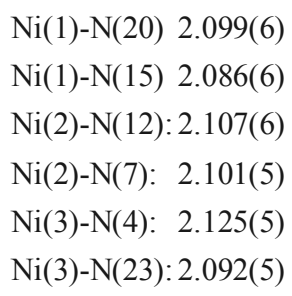$$
\mathrm{Ni}(1)-\mathrm{N}(19) 2.118(6)
$$

$(1)-\mathrm{N}(14) 2.095(7)$

$\mathrm{Ni}(1)-\mathrm{N}(1) \quad 2.138(6)$

$\mathrm{Ni}(2)-\mathrm{O}(5): 2.110(5)$

$\mathrm{Ni}(2)-\mathrm{N}(11): 2.086(6)$

$\mathrm{Ni}(2)-\mathrm{N}(17): 2.151(5)$

$\mathrm{Ni}(3)-\mathrm{O}(2): 2.086(5)$

$\mathrm{Ni}(3)-\mathrm{N}(3): 2.131(6)$

$\mathrm{Ni}(3)-\mathrm{N}(22): 2.097(5)$

$\mathrm{Ni}(3)-\mathrm{N}(9): 2.098(6)$

Units / $\AA$

Table S13. Bond angles of the $\mathrm{Ni}(\mathrm{II})$ center in the block-like crystals of the $\mathbf{1}_{12} \mathrm{Ni}_{12}$ complex.

\section{$\mathrm{O}(8)-\mathrm{Ni}(1)-\mathrm{N}(20)$}

$\mathrm{N}(20)-\mathrm{Ni}(1)-\mathrm{N}(19)$

$\mathrm{N}(1)-\mathrm{Ni}(1)-\mathrm{N}(20)$

$89.2(2)$

$85.8(3)$

95.2(2)

82.4(2)

$\mathrm{O}(5)-\mathrm{Ni}(2)-\mathrm{N}(12)$

$\mathrm{N}(12)-\mathrm{Ni}(2)-\mathrm{N}(11)$ :

$85.6(2)$

$\mathrm{N}(17)-\mathrm{Ni}(2)-\mathrm{N}(12)$ :

96.7(2)

$81.7(2)$

$\mathrm{O}(2)-\mathrm{Ni}(3)-\mathrm{N}(3)$ :

$\mathrm{N}(3)-\mathrm{Ni}(3)-\mathrm{N}(4)$ :

$\mathrm{N}(9)-\mathrm{Ni}(3)-\mathrm{N}(3)$ :

$86.6(2)$

96.4(2)

Unit / $\circ$
$\mathrm{O}(8)-\mathrm{Ni}(1)-\mathrm{N}(19)$

$\mathrm{N}(19)-\mathrm{Ni}(1)-\mathrm{N}(14)$

$\mathrm{N}(1)-\mathrm{Ni}(1)-\mathrm{N}(19)$

$81.8(2)$

$92.0(3)$

$95.7(2)$

(1)-N(14)

$\mathrm{N}(14)-\mathrm{Ni}(1)-\mathrm{N}(15)$

$\mathrm{N}(1)-\mathrm{Ni}(1)-\mathrm{N}(14)$

$91.2(2)$

$89.0(2)$

$86.6(2)$

$\mathrm{O}(5)-\mathrm{Ni}(2)-\mathrm{N}(11)$ :

$88.1(2)$

$\mathrm{O}(5)-\mathrm{Ni}(2)-\mathrm{N}(6)$ :

$\mathrm{N}(6)-\mathrm{Ni}(2)-\mathrm{N}(7)$ :

$\mathrm{N}(17)-\mathrm{Ni}(2)-\mathrm{N}(11)$ :

93.3(2)

$\mathrm{N}(17)-\mathrm{Ni}(2)-\mathrm{N}(6)$

90.0(2)

94.3(2)

$84.5(2)$

(2)-Ni(3)-N(4):

$\mathrm{N}(4)-\mathrm{Ni}(3)-\mathrm{N}(23)$ :

$88.8(2)$

$\mathrm{O}(2)-\mathrm{Ni}(3)-\mathrm{N}(23)$ :

$\mathrm{N}(23)-\mathrm{Ni}(3)-\mathrm{N}(22)$ :

$\mathrm{N}(9)-\mathrm{Ni}(3)-\mathrm{N}(23)$ :
$89.8(2)$

97.5(2)
$\mathrm{O}(8)-\mathrm{Ni}(1)-\mathrm{N}(15)$

$\mathrm{N}(15)-\mathrm{Ni}(1)-\mathrm{N}(20) \quad 90.1(2)$

$\mathrm{N}(1)-\mathrm{Ni}(1)-\mathrm{N}(15)$

$\mathrm{O}(5)-\mathrm{Ni}(2)-\mathrm{N}(7): \quad 85.3(2)$

$\mathrm{N}(7)-\mathrm{Ni}(2)-\mathrm{N}(12): \quad \quad 89.2(2)$

$\mathrm{N}(17)-\mathrm{Ni}(2)-\mathrm{N}(7): \quad 93.3(2)$

$\mathrm{O}(2)-\mathrm{Ni}(3)-\mathrm{N}(22): \quad 86.8(2)$

$\mathrm{N}(3)-\mathrm{Ni}(3)-\mathrm{N}(22): \quad 91.6(2)$

$\mathrm{N}(9)-\mathrm{Ni}(3)-\mathrm{N}(22): \quad 89.6(2)$ 


\section{3-4. Additional information concerning the crystal structure of the $\left(1-3 \mathrm{H}^{+}\right)_{4} \mathrm{Ni}_{8}$ complex}

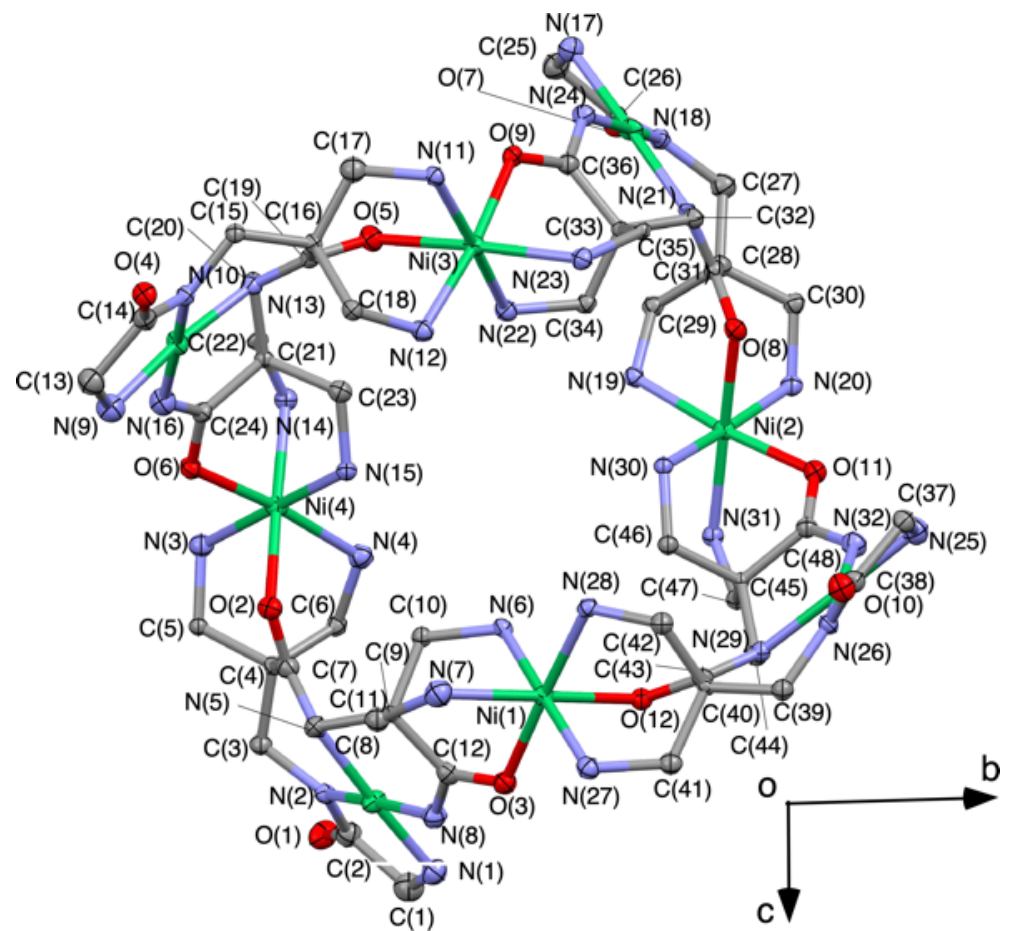

Figure S12. Molecular structure of $\left[\left(1-3 \mathrm{H}^{+}\right)_{4} \mathrm{Ni}_{8}\right]^{4+}$ with $50 \%$ thermal ellipsoids viewed along the $c$ axis. The atom numbers are plotted for one of the configurations of $\mathbf{1}$. Counteranions, crystal solvent molecules, and hydrogen atoms are omitted for clarity (please refer to the note shown below).

Note: The peptides in the cyclic structure are four crystallographically independent molecules. Thus, two peptides have similar conformation and the other two peptides have an inverted conformation. 


\section{Conformation of the peptides in the block-like crystals of the $\left(1-3 \mathrm{H}^{+}\right)_{4} \mathrm{Ni}_{8}$ complex}

a)
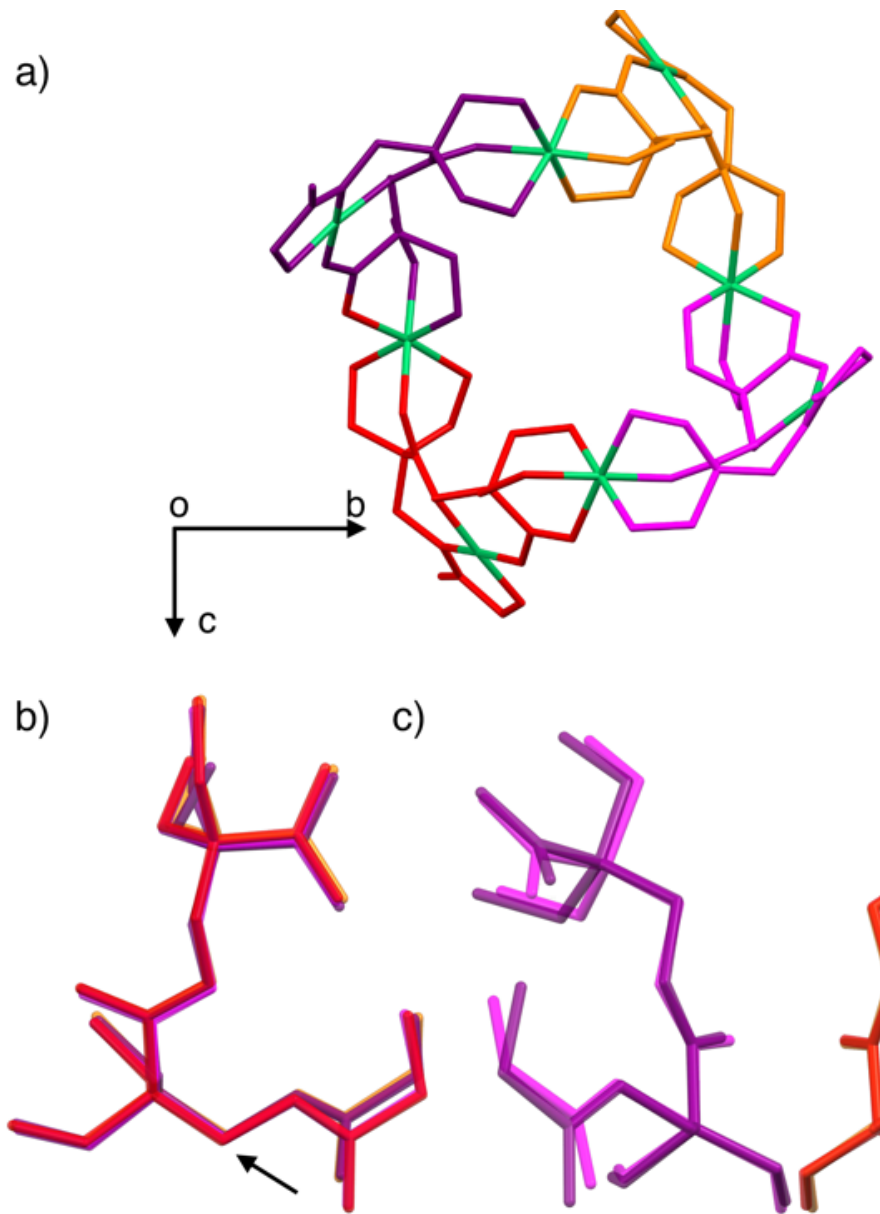

c)

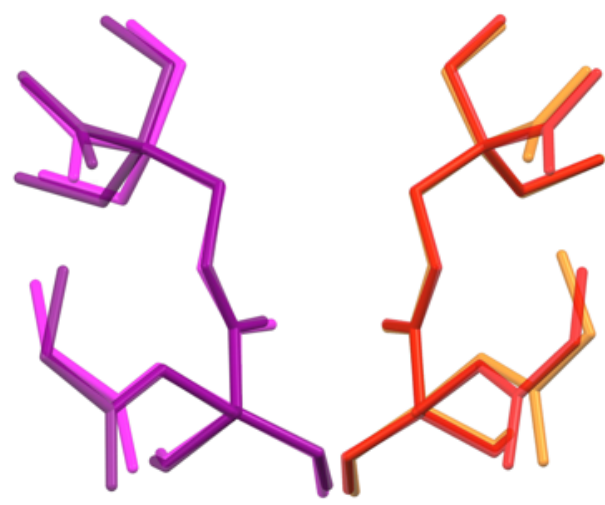

Figure S13. Cyclic structure of the $\left(1-3 \mathrm{H}^{+}\right)_{4} \mathrm{Ni}_{8}$ complex showing the crystallographically independent peptides in different colors and (a) a comparison of each peptide conformation from different angles (b) and (c). The arrow in (b) represents the viewing angle in (c). Colors in (b) and (c) are shown with 75\% transparency.

Table S14. Bond angles around the methylene group in the peptide main chain of the block-like crystals of the $\left(1-3 \mathrm{H}^{+}\right)_{4} \mathrm{Ni}_{8}$ complex.

$\begin{array}{llllll}\mathrm{N}(1)-\mathrm{C}(1)-\mathrm{C}(2) & 109(1) & \mathrm{N}(2)-\mathrm{C}(3)-\mathrm{C}(4) & 112(1) & \mathrm{N}(5)-\mathrm{C}(8)-\mathrm{C}(9) & 114(1) \\ \mathrm{N}(9)-\mathrm{C}(13)-\mathrm{C}(14) & 109(1) & \mathrm{N}(10)-\mathrm{C}(15)-\mathrm{C}(16) & 114(1) & \mathrm{N}(13)-\mathrm{C}(20)-\mathrm{C}(21) & 114(1) \\ \mathrm{N}(17)-\mathrm{C}(25)-\mathrm{C}(26) & 109(1) & \mathrm{N}(18)-\mathrm{C}(27)-\mathrm{C}(28) & 113(1) & \mathrm{N}(21)-\mathrm{C}(32)-\mathrm{C}(33) & 116(1) \\ \mathrm{N}(25)-\mathrm{C}(37)-\mathrm{C}(38) & 109(1) & \mathrm{N}(26)-\mathrm{C}(39)-\mathrm{C}(40) & 113(1) & \mathrm{N}(29)-\mathrm{C}(44)-\mathrm{C}(45) & 115(1)\end{array}$

Unit ${ }^{\circ}$

Table S15. Torsion angles along the methylene groups in the peptide main chain of the block-like crystals of the $\left(1-3 \mathrm{H}^{+}\right)_{4} \mathrm{Ni}_{8}$ complex.

$\begin{array}{llll}\mathrm{C}(2)-\mathrm{N}(2)-\mathrm{C}(3)-\mathrm{C}(4) & -135(1) & \mathrm{N}(2)-\mathrm{C}(3)-\mathrm{C}(4)-\mathrm{C}(7) & -59(2) \\ \mathrm{C}(7)-\mathrm{N}(5)-\mathrm{C}(8)-\mathrm{C}(9) & -107(1) & \mathrm{N}(5)-\mathrm{C}(8)-\mathrm{C}(9)-\mathrm{C}(11) & -178(1) \\ \mathrm{C}(14)-\mathrm{N}(10)-\mathrm{C}(15)-\mathrm{C}(16) & 136(1) & \mathrm{N}(10)-\mathrm{C}(15)-\mathrm{C}(16)-\mathrm{C}(19) & 58(2) \\ \mathrm{C}(19)-\mathrm{N}(13)-\mathrm{C}(20)-\mathrm{C}(21) & 108(1) & \mathrm{N}(13)-\mathrm{C}(20)-\mathrm{C}(21)-\mathrm{C}(23) & -64(2) \\ \mathrm{C}(26)-\mathrm{N}(18)-\mathrm{C}(27)-\mathrm{C}(28) & -116(1) & \mathrm{N}(18)-\mathrm{C}(27)-\mathrm{C}(28)-\mathrm{C}(31) & -56(2) \\ \mathrm{C}(31)-\mathrm{N}(21)-\mathrm{C}(32)-\mathrm{C}(33) & -110(1) & \mathrm{N}(21)-\mathrm{C}(32)-\mathrm{C}(33)-\mathrm{C}(35) & -177.1(11) \\ \mathrm{C}(38)-\mathrm{N}(26)-\mathrm{C}(39)-\mathrm{C}(40) & 120(1) & \mathrm{N}(26)-\mathrm{C}(39)-\mathrm{C}(40)-\mathrm{C}(43) & 55(2)\end{array}$

Unit/ ${ }^{\circ}$ 


\section{Comparison of each $\mathrm{Ni}(\mathrm{II})$ center in the block-like crystal of $\left(1-3 \mathrm{H}^{+}\right)_{4} \mathrm{Ni}_{8}$ complex}

Table S16. Lengths of coordination bonds at the octahedral $\mathrm{Ni}(\mathrm{II})$ centers in the $\left(\mathbf{1}-3 \mathrm{H}^{+}\right)_{4} \mathrm{Ni}_{8}$ complex.

\begin{tabular}{|c|c|c|c|c|c|}
\hline (1)-N(6) & 2.1 & I(7) & 2.0 & $\mathrm{~N}$ & \\
\hline $\mathrm{Ni}(1)-\mathrm{N}(28)$ & $2.12(1)$ & $\mathrm{Ii}(1)-\mathrm{O}(3)$ & $2.053(10)$ & $\mathrm{Ni}(1)-\mathrm{O}(12)$ & $2.053(10$ \\
\hline i $(3$ & & $-\mathrm{N}(20)$ & 2.12 & & \\
\hline & & (8) & 2.08 & & (10) \\
\hline $\mathrm{i}(3)-\mathrm{N}(11)$ & $2.06(1)$ & $\mathrm{J}(12)$ & 2.11 & $\mathrm{Ni}$ & $2.08(1)$ \\
\hline i(3) & $2.10(1)$ & (5) & 2.10 & $\mathrm{Ni}(3)-\mathrm{O}(9)$ & $.044(10)$ \\
\hline i(4)-N(3) & $2.06(1)$ & $\mathrm{Ni}(4)-\mathrm{N}(4)$ & $2.13(1)$ & $\mathrm{Ni}(4)-\mathrm{N}(14)$ & $2.09(1)$ \\
\hline $\mathrm{i}(4)-\mathrm{N}(15)$ & $2.12(1)$ & $\mathrm{Ni}(4)-\mathrm{O}(2)$ & $2.079(10)$ & $\mathrm{Ni}(4)-\mathrm{O}(06)$ & $2.063(10)$ \\
\hline
\end{tabular}

Units / $\AA$

Table S17. Bond angles at each octahedral Ni(II) center in the $\left(1-3 \mathrm{H}^{+}\right)_{4} \mathrm{Ni}_{8}$ complex.

\begin{tabular}{|c|c|c|c|c|c|c|c|}
\hline $\mathrm{N}(6)-\mathrm{Ni}(1)-\mathrm{N}(7)$ & $89.1(5)$ & $\mathrm{N}(7)-\mathrm{Ni}(1)-\mathrm{N}(3)$ & $95.8(5)$ & $\mathrm{N}(7)-\mathrm{Ni}(1)-\mathrm{N}(27)$ & $94.6(5)$ & $\mathrm{N}(7)-\mathrm{Ni}(1)-\mathrm{N}(28)$ & $95.3(5)$ \\
\hline $\mathrm{N}(27)-\mathrm{Ni}(1)-\mathrm{N}(28)$ & $87.3(5)$ & $\mathrm{N}(6)-\mathrm{Ni}(1)-\mathrm{O}(3)$ & $84.8(4)$ & $\mathrm{N}(6)-\mathrm{Ni}(1)-\mathrm{O}(12)$ & $86.4(4)$ & $\mathrm{N}(7)-\mathrm{Ni}(1)-\mathrm{O}(3)$ & $86.8(5)$ \\
\hline $\mathrm{N}(27)-\mathrm{Ni}(1)-\mathrm{O}(3)$ & $92.0(5)$ & $\mathrm{N}(27)-\mathrm{Ni}(1)-\mathrm{O}(12)$ & $89.7(5)$ & $\mathrm{N}(28)-\mathrm{Ni}(1)-\mathrm{O}(12)$ & $88.7(4)$ & $\mathrm{O}(3)-\mathrm{Ni}(1)-\mathrm{O}(12)$ & $89.3(4)$ \\
\hline N(19)-Ni(2)-N(20) & $86.4(5)$ & N(19)-Ni(2)-N(30) & $95.9(5)$ & $\mathrm{N}(19)-\mathrm{Ni}(2)-\mathrm{N}(31)$ & $98.8(5)$ & $\mathrm{N}(20)-\mathrm{Ni}(2)-\mathrm{N}(31)$ & $96.3(5)$ \\
\hline N(30)-Ni(2)-N(31) & $89.5(5)$ & $\mathrm{N}(19)-\mathrm{Ni}(2)-\mathrm{O}(8)$ & $84.9(4)$ & $\mathrm{N}(20)-\mathrm{Ni}(2)-\mathrm{O}(8)$ & $88.3(4)$ & $\mathrm{N}(20)-\mathrm{Ni}(2)-\mathrm{O}(11)$ & $91.2(5)$ \\
\hline $\mathrm{N}(30)-\mathrm{Ni}(2)-\mathrm{O}(8)$ & $85.7(4)$ & $\mathrm{N}(30)-\mathrm{Ni}(2)-\mathrm{O}(11)$ & $86.0(4)$ & $\mathrm{N}(31)-\mathrm{Ni}(2)-\mathrm{O}(11)$ & $86.3(4)$ & $\mathrm{O}(8)-\mathrm{Ni}(2)-\mathrm{O}(11)$ & $90.2(4)$ \\
\hline $\mathrm{N}(11)-\mathrm{Ni}(3)-\mathrm{N}(12)$ & $84.7(5)$ & $\mathrm{N}(11)-\mathrm{Ni}(3)-\mathrm{N}(23)$ & $97.6(5)$ & $\mathrm{N}(12)-\mathrm{Ni}(3)-\mathrm{N}(22)$ & $97.7(5)$ & $\mathrm{N}(12)-\mathrm{Ni}(3)-\mathrm{N}(23)$ & $97.9(5)$ \\
\hline N(22)-Ni(3)-N(23) & $87.7(5)$ & $\mathrm{N}(11)-\mathrm{Ni}(3)-\mathrm{O}(5)$ & $89.8(4)$ & $\mathrm{N}(11)-\mathrm{Ni}(3)-\mathrm{O}(9)$ & $90.9(4)$ & $\mathrm{N}(12)-\mathrm{Ni}(3)-\mathrm{O}(5)$ & $84.6(5)$ \\
\hline $\mathrm{N}(22)-\mathrm{Ni}(3)-\mathrm{O}(5)$ & $84.9(4)$ & $\mathrm{N}(22)-\mathrm{Ni}(3)-\mathrm{O}(9)$ & $86.1(4)$ & $\mathrm{N}(23)-\mathrm{Ni}(3)-\mathrm{O}(9)$ & $87.7(5)$ & $\mathrm{O}(5)-\mathrm{Ni}(3)-\mathrm{O}(9)$ & $90.3(4)$ \\
\hline $\mathrm{N}(3)-\mathrm{Ni}(4)-\mathrm{N}(4)$ & $86.8(5)$ & $\mathrm{N}(3)-\mathrm{Ni}(4)-\mathrm{N}(14)$ & $96.1(5)$ & $\mathrm{N}(4)-\mathrm{Ni}(4)-\mathrm{N}(15)$ & $96.9(5)$ & $\mathrm{N}(4)-\mathrm{Ni}(4)-\mathrm{N}(14)$ & $96.6(5)$ \\
\hline $\mathrm{N}(14)-\mathrm{Ni}(4)-\mathrm{N}(15)$ & $88.0(5)$ & $\mathrm{N}(3)-\mathrm{Ni}(4)-\mathrm{O}(2)$ & $88.8(5)$ & $\mathrm{N}(4)-\mathrm{Ni}(4)-\mathrm{O}(2)$ & $86.1(4)$ & $\mathrm{N}(14)-\mathrm{Ni}(4)-\mathrm{O}(6)$ & $88.8(4)$ \\
\hline $\mathrm{N}(15)-\mathrm{Ni}(4)-\mathrm{O}(2)$ & $86.9(4)$ & $\mathrm{N}(15)-\mathrm{Ni}(4)-\mathrm{O}(6)$ & $85.4(4)$ & $\mathrm{N}(3)-\mathrm{Ni}(4)-\mathrm{O}(6)$ & $90.5(5)$ & $\mathrm{O}(2)-\mathrm{Ni}(4)-\mathrm{O}(6)$ & $88.8(4)$ \\
\hline
\end{tabular}


3-5. Additional data for comparison of the peptide conformation between the $1_{14} \mathrm{Ni}_{14}$ complex and $\left(1-3 \mathrm{H}^{+}\right)_{4} \mathrm{Ni}_{8}$ complex

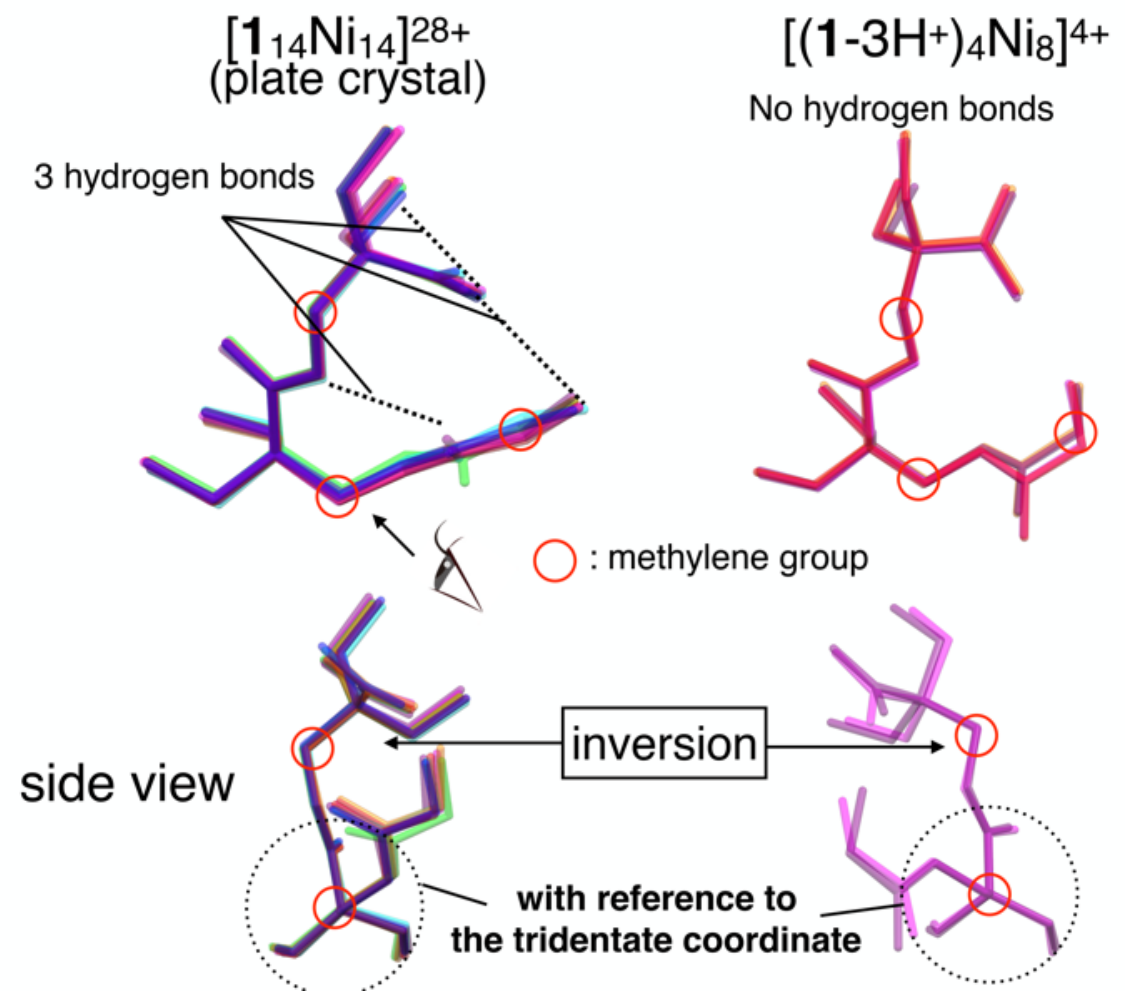

Figure S14. Comparison of the peptide conformation in the plate-like crystals of $\mathbf{1}_{14} \mathrm{Ni}_{14}$ and (1$\left.3 \mathrm{H}^{+}\right)_{4} \mathrm{Ni}_{8}$ complexes. Only two conformations are shown for the $\left(1-3 \mathrm{H}^{+}\right)_{4} \mathrm{Ni}_{8}$ complex in side view because the others have the inverse conformation. For the color scheme, please refer to Figures S10 and S13. 


\section{3-6. Additional information concerning the packing structure of the plate-like crystals of the $1_{14} \mathrm{Ni}_{14}$ complex}

a)

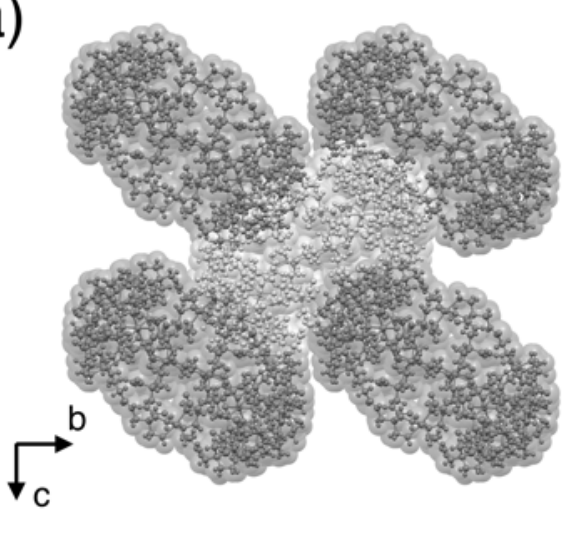

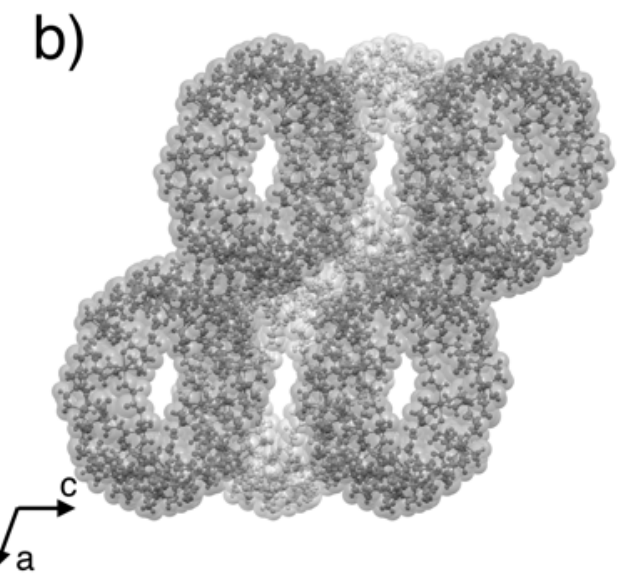

Figure S15. Crystal packing structure of plate-like crystals of the $\mathbf{1}_{14} \mathrm{Ni}_{14}$ complex along the $a$ - (a) and $b$-axes (b). To aid understanding, the neighboring cyclic complexes are colored grey and dark grey, respectively.

a)
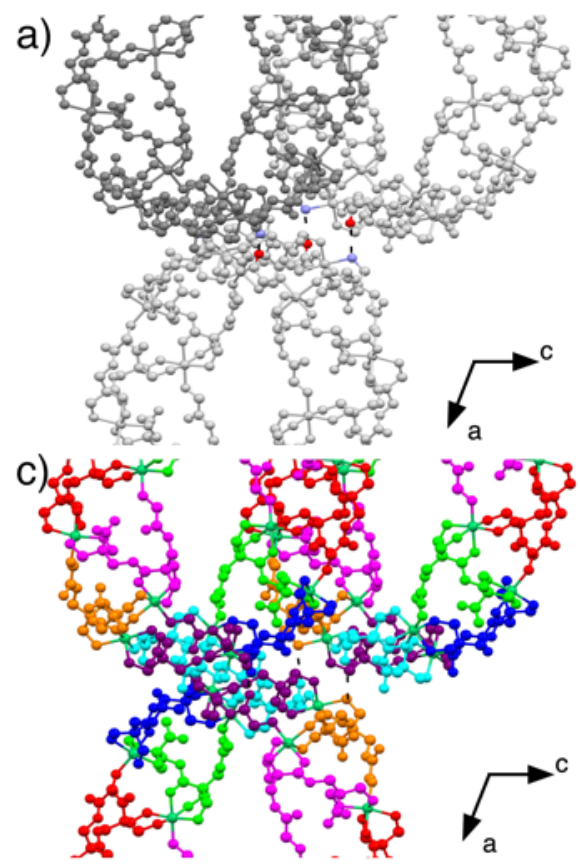

b)

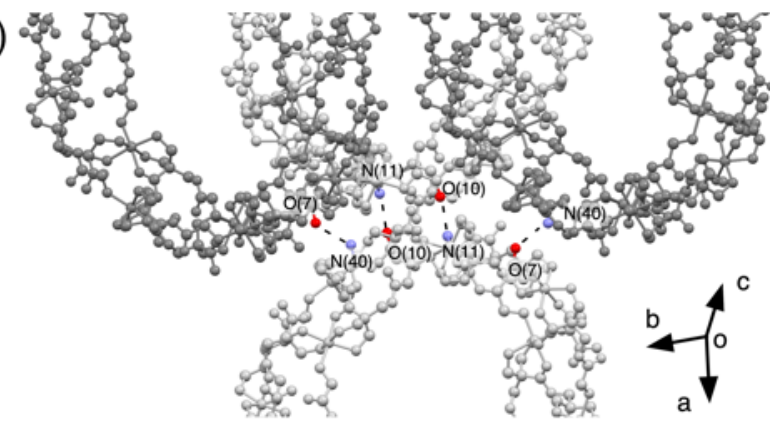

d)

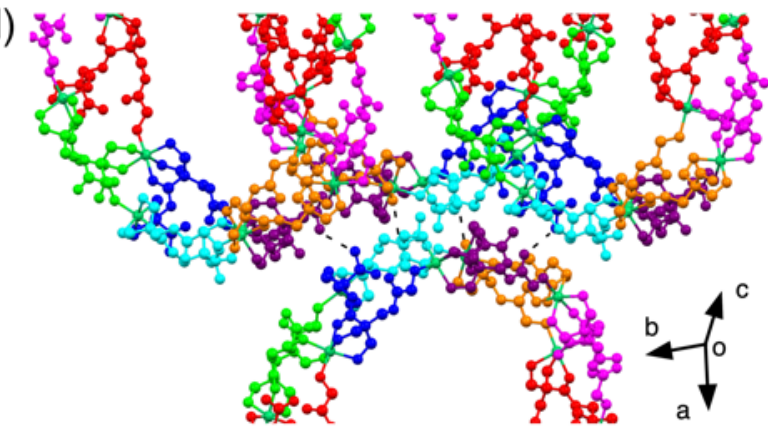

Figure S16. Intermolecular interactions in the plate-like crystals of the $\mathbf{1}_{14} \mathrm{Ni}_{14}$ complex along the aaxis $(a, c)$ and from a different perspective $(b, d)$. To aid understanding, the cyclic frameworks were drawn using same colors as in Figure S15 (a, b) and Figure S10 (c, d). Hydrogen bonds are shown using dashed lines.

Table S18. Short contacts suggesting the formation of hydrogen bonds between cyclic complexes in the plate-like crystals of the $\mathbf{1}_{14} \mathrm{Ni}_{14}$ complex. (For atom numbering, please refer to Figure S16.)
$\mathrm{O}(7)-\mathrm{N}(40)$
$3.013(7)$
$\mathrm{O}(10)-\mathrm{N}(11)$
$2.985(6)$

Unit/ $\AA$ 
a) $\quad \mathbf{1}_{12} \mathrm{Ni}_{12}$ complex (block-like crystal)

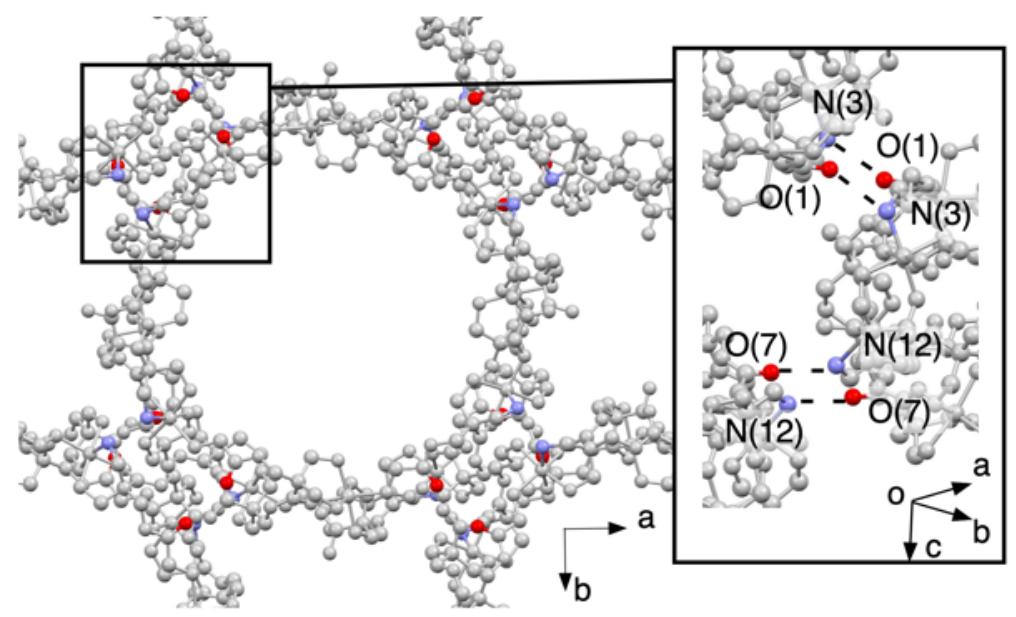

b) $\mathbf{1}_{14} \mathrm{Ni}_{14}$ complex (needle-like crystal)

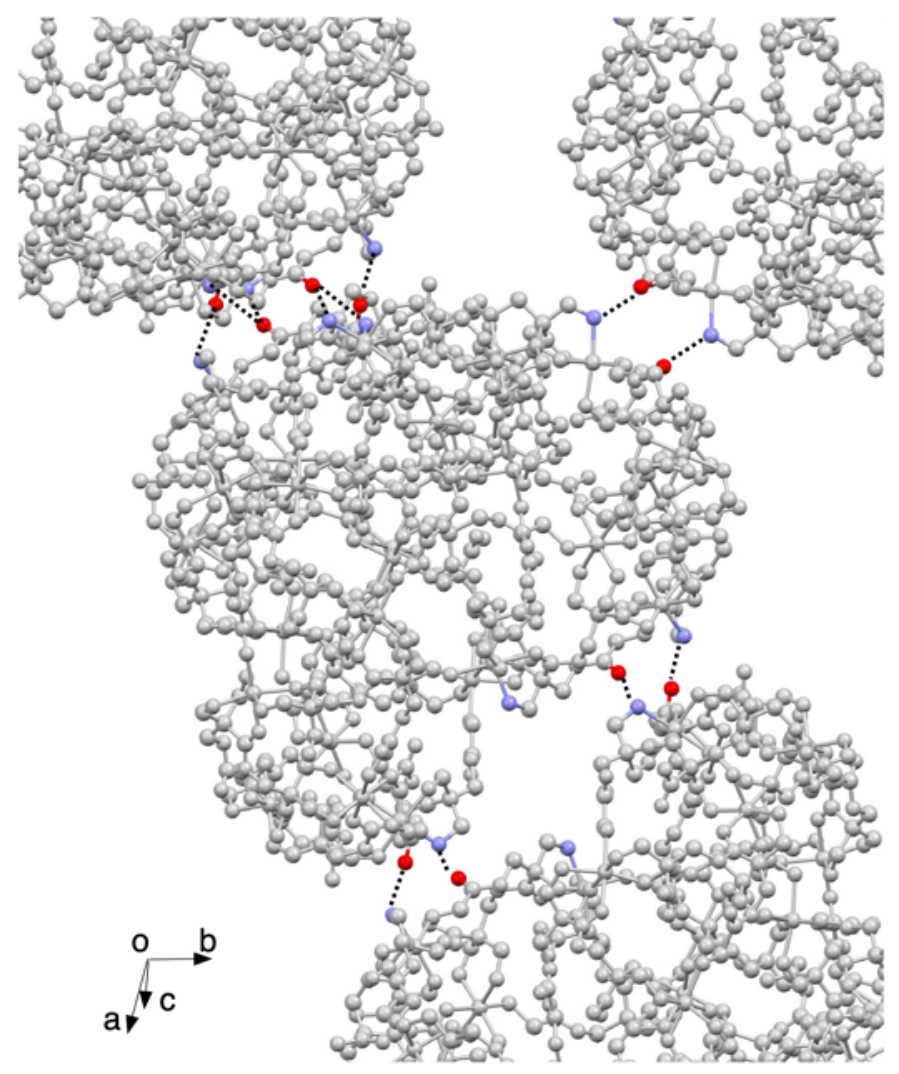

Figure S17. Intermolecular interactions in the block-like crystals of the $\mathbf{1}_{12} \mathrm{Ni}_{12}$ complex (a) and the needle-like crystals of the $\mathbf{1}_{14} \mathrm{Ni}_{14}$ complex (b). Hydrogen bonds are shown using dashed lines.

Table S19. Short contacts suggesting the formation of hydrogen bonds between cyclic complexes in the $\mathbf{1}_{12} \mathrm{Ni}_{12}$ complex. (For atom numbering, please refer to Figure $\mathrm{S} 17 \mathrm{a}$.)
$\mathrm{O}(1)-\mathrm{N}(3)$
$3.130(8)$
$\mathrm{O}(7)-\mathrm{N}(12)$
$2.915(6)$

Unit/ $\AA$

Note: We have not included tables of short contacts in the needle-like crystal of the $\mathbf{1}_{14} \mathrm{Ni}_{14}$ complex since there were large uncertainties in the values due to low data resolution. 


\section{3-7. Discussion of the intermolecular interactions between cyclic complexes and the reason for the formation of the ellipsoidal framework}

As shown in Figure S16, direct contacts were observed between $\mathbf{1}_{14} \mathrm{Ni}_{14}$ complexes for four of seven crystallographically independent peptide conformations (i.e. blue, sky blue, purple, and orange). This means that anisotropic intermolecular interactions are formed in the plate-like crystals. Asymmetric interactions are also observed between the $\mathbf{1}_{14} \mathrm{Ni}_{14}$ complexes in the needle-like crystals, as shown in Figure S17b. Thus, the formation of the catenane structure is key to retaining the cyclic framework. In contrast, although the $\mathbf{1}_{14} \mathrm{Ni}_{14}$ complex of $\mathrm{TfO}$ salt do not form catenane structure in crystalline packing structure, the TfO salt of $\mathbf{1}_{14} \mathrm{Ni}_{14}$ complex is also a cyclic structure (does not form an ellipsoidal sturcture). In this structure, no direct intermolecular interactions are observed between the cyclic structures because of the large size of the $\mathrm{TfO}$ anions in contrast with the smaller $\mathrm{NO}_{3}$ anions (Figure S6). These results indicated that anisotropic contacts and a dense crystal packing structure are key to the formation of the observed ellipsoidal structure: the use of small counter anions that can form dense packing structures through intermolecular interactions (such as the $\mathrm{NO}_{3}{ }^{-}$ion), are needed. 


\section{Computational study of the large cyclic complex of 1}

The optimization of the peptide structure was achieved starting from one of the conformations of the Ni(II) complexes observed in the plate-like crystal (colored orange in Figure S9) by DFT calculation (functional: B3PW91, basis set: 6-31G(d,p) in the quantum package Gaussian 16). To restrict the coordination around the metal binding sites, the distances between $\mathrm{N}$ atoms or $\mathrm{O}$ atoms in the tridentate and bidentate binding sites (* in Figure S18b) were fixed by using the "Redundant coordinates" instruction. As shown in Figure S18, when this restriction was applied, the optimized structure retains the hydrogen-bond network (shown with dashed lines in Figure S18) and conformations of 1 at the coordination sites. In contrast, the optimized structures calculated without the restriction have completely different conformations as shown in Figure S18c.
a) Original structure

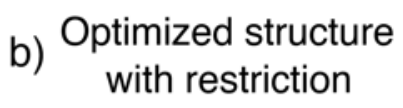

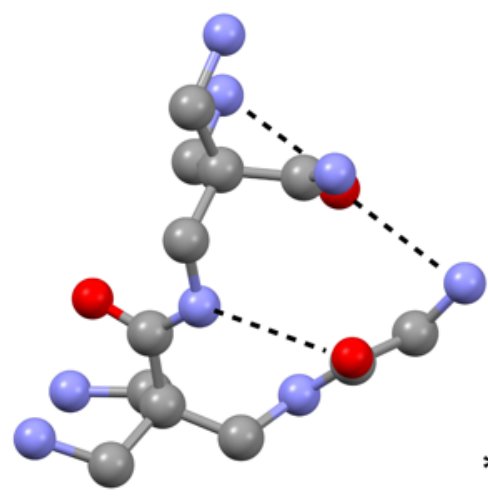

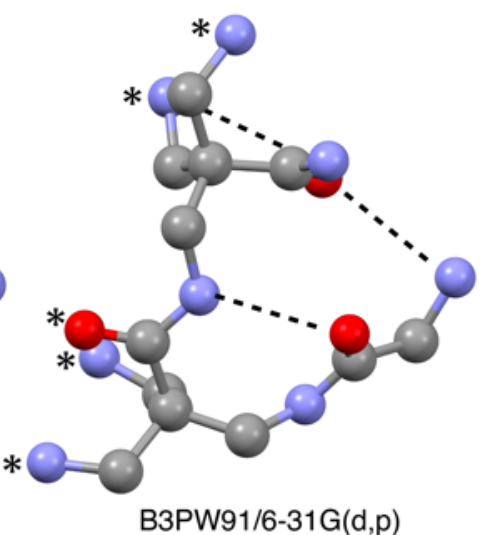

c) Optimized structure

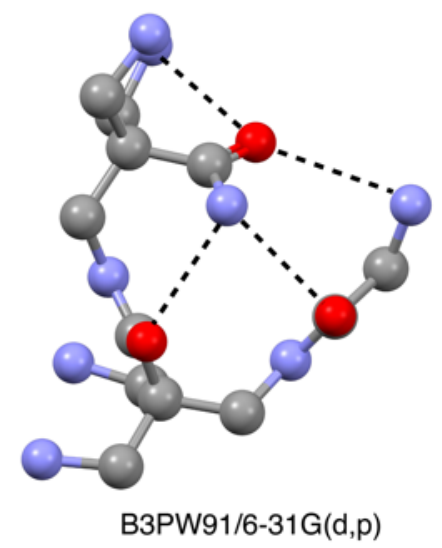

Figure S18. Comparison of structures of 1 in the giant cyclic crystalline Ni(II) complex (a) and the DFT-optimized structure (B3PW91/6-31G(d,p)) with (b) and without the distance restriction at the tridentate and bidentate coordination site (c). Hydrogen bonds are shown using dash lines. Hydrogen atoms are omitted for clarity. 


\section{Additional characterization of the cyclic $\mathrm{Ni}$ (II) complexes of 1}

Infrared spectrum of the crystalline cyclic complexes of tripeptide 1 as a $\mathrm{NO}_{3}$ salt.
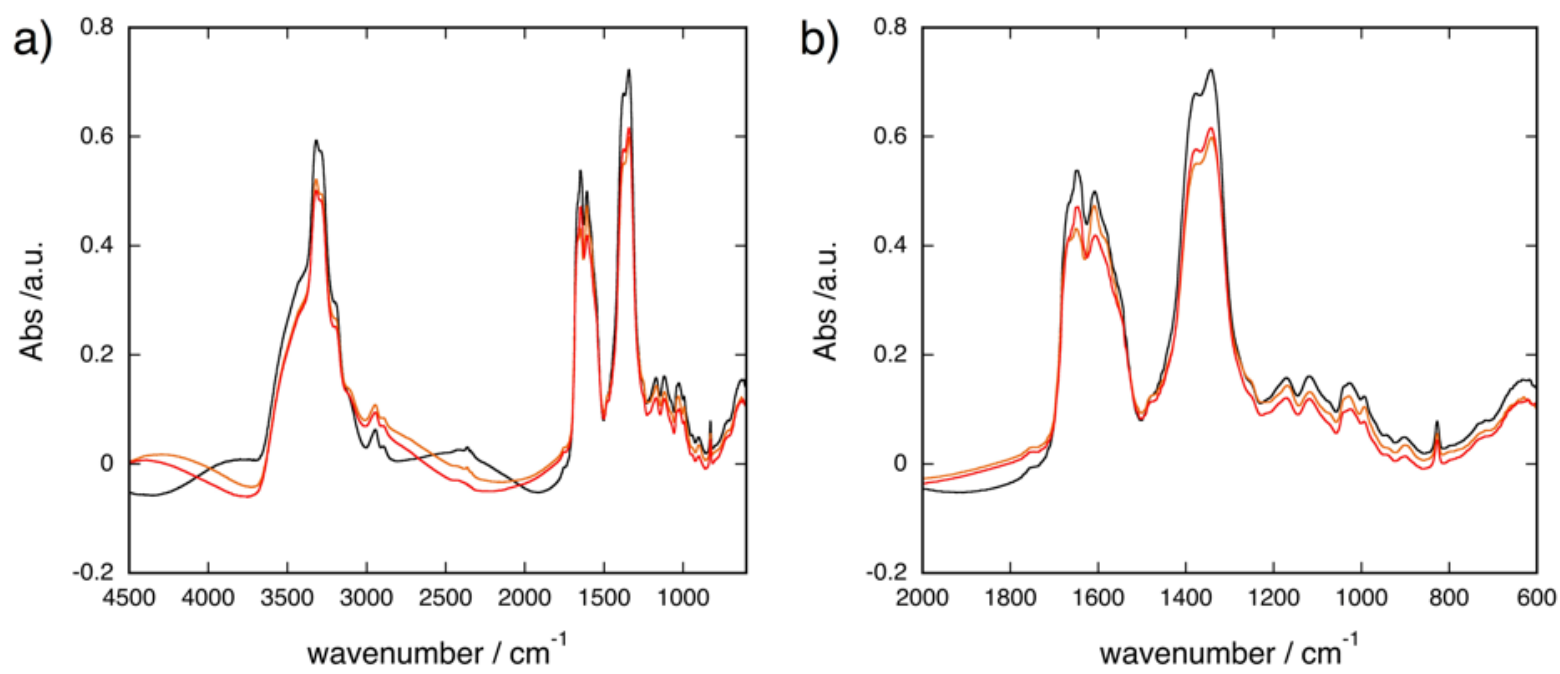

Figure S19. Infrared spectrum of single crystals of the Ni(II) complex of 1 in all range (a) and 600 $2000 \mathrm{~cm}^{-1}$ (b) (black line: block-like crystals of $\mathbf{1}_{12} \mathrm{Ni}_{12}$ complex, orange line: needle-like crystals of $\mathbf{1}_{14} \mathrm{Ni}_{14}$ complex, and red line: plate-like crystals of $\mathbf{1}_{14} \mathrm{Ni}_{14}$ complex). Measurements were carried out on crushed samples in infrared transmission mode.

\section{Raman spectrum of crystalline cyclic complexes of tripeptide 1 as a $\mathrm{NO}_{3}$ salt.}

a)
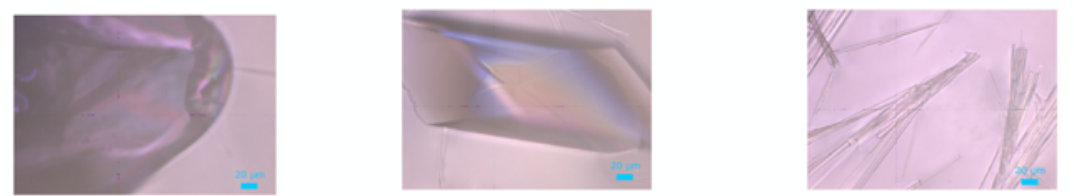

block-like_1 ${ }_{12} \mathrm{Ni}_{12}$ plate-like_1 ${ }_{14} \mathrm{Ni}_{14}$ needle-like_1 ${ }_{14} \mathrm{Ni}_{14}$
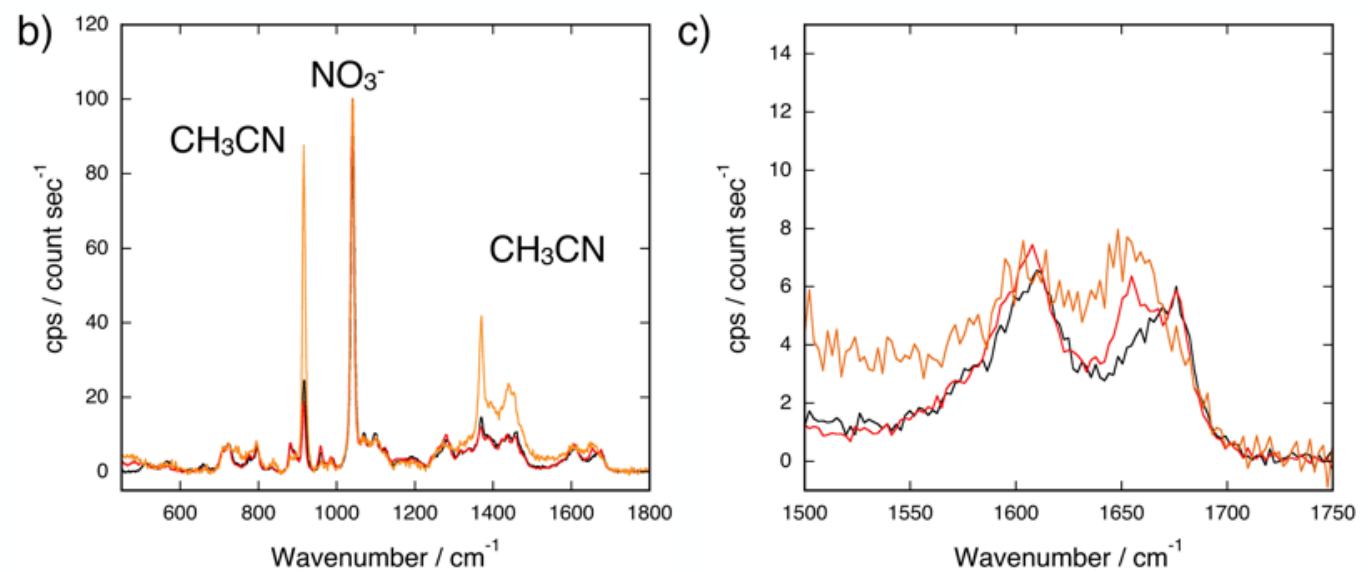

Figure S20. Photograph of single crystals of the Ni(II) complex of 1 whose Raman spectra were measured (a) and the Raman spectrum and (b) that between 1500 and $1750 \mathrm{~cm}^{-1}$ (c) (black line: blocklike crystals of $\mathbf{1}_{12} \mathrm{Ni}_{12}$ complex, orange line: needle-like crystals of $\mathbf{1}_{14} \mathrm{Ni}_{14}$ complex, and red line: platelike crystals of $\mathbf{1}_{14} \mathrm{Ni}_{14}$ complex).

Note: We thank to Ms. Tomoko Numata (Horiba, Ltd) for the Raman spectra measurements. 


\section{Additional description of Raman spectra of the cyclic complexes of 1.}

The intensity of peaks of solvent molecule was strong since Raman spectra were measured in the solution in which the single crystal was obtained. It is noteworthy that Raman spectra around 1550$1700 \mathrm{~cm}^{-1}$ are useful to distinguish these crystals (i.e. plate or block-like crystal of $\mathbf{1}_{14} \mathrm{Ni}_{14}$ complex and block crystal of $\mathbf{1}_{12} \mathrm{Ni}_{12}$ complex) even if the shape of crystals were not clear.

\section{Characterization of the cyclic $\mathrm{Ni}$ (II) complexes of 1 in the solution state}

ca. $2 \mathrm{~nm}$

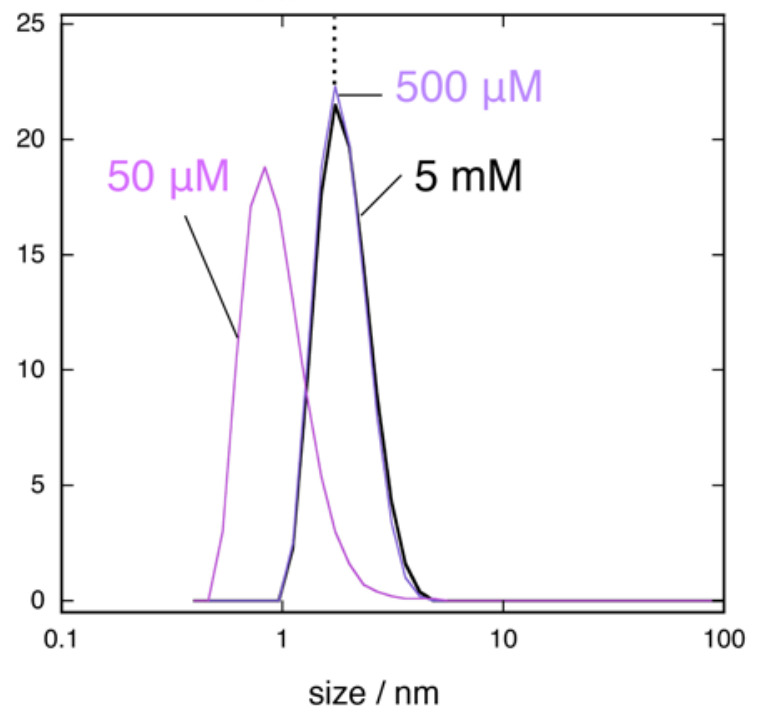

Figure S21. DLS curve of water solution of needle-like crystals of the $\mathbf{1}_{14} \mathrm{Ni}_{14}$ complex at various concentrations at $20^{\circ} \mathrm{C}$ (black: $5 \mathrm{mM}$, purple: $0.5 \mathrm{mM}$, and pink: $0.05 \mathrm{mM}$ ).

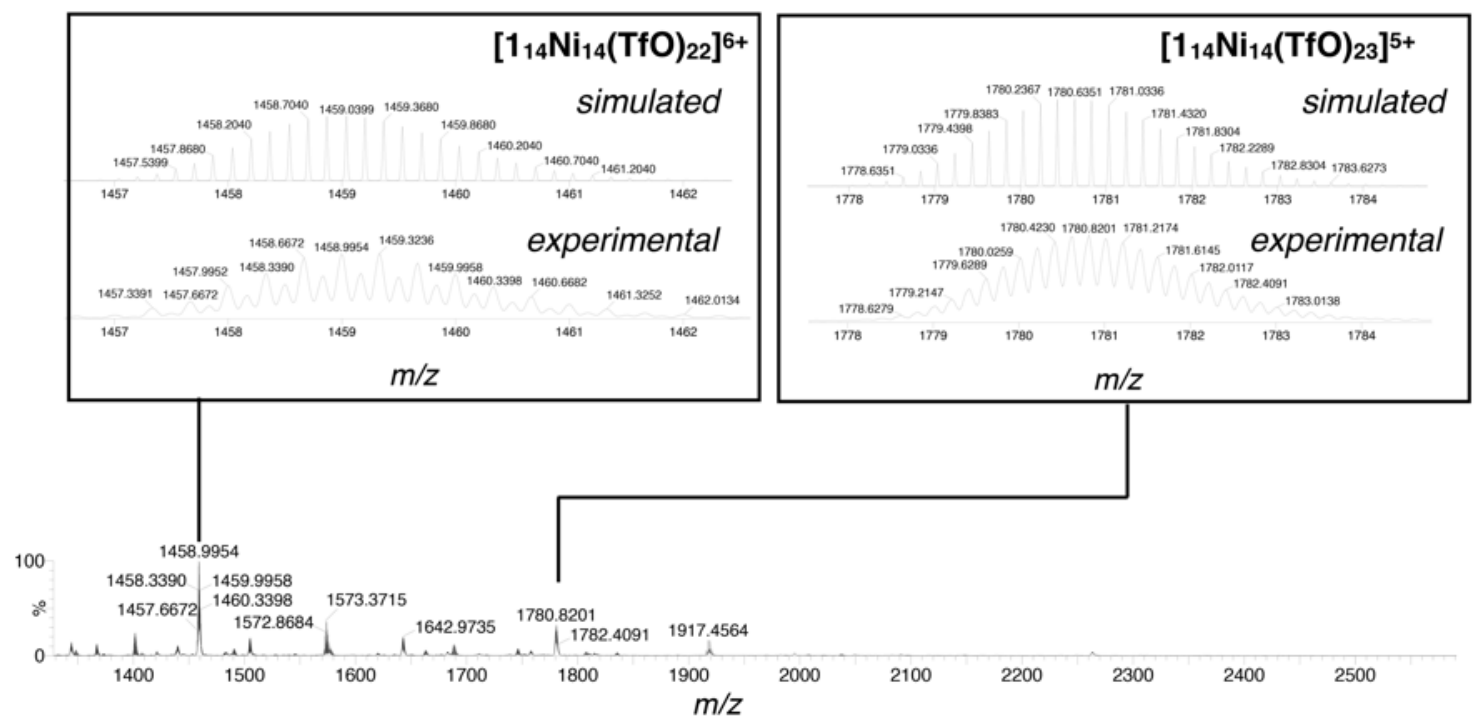

Figure S22. ESI-TOF mass spectrum of the $\mathbf{1}_{14} \mathrm{Ni}_{14}(\mathrm{TfO})_{28}$ complex in $\mathrm{CH}_{3} \mathrm{CN}$. 


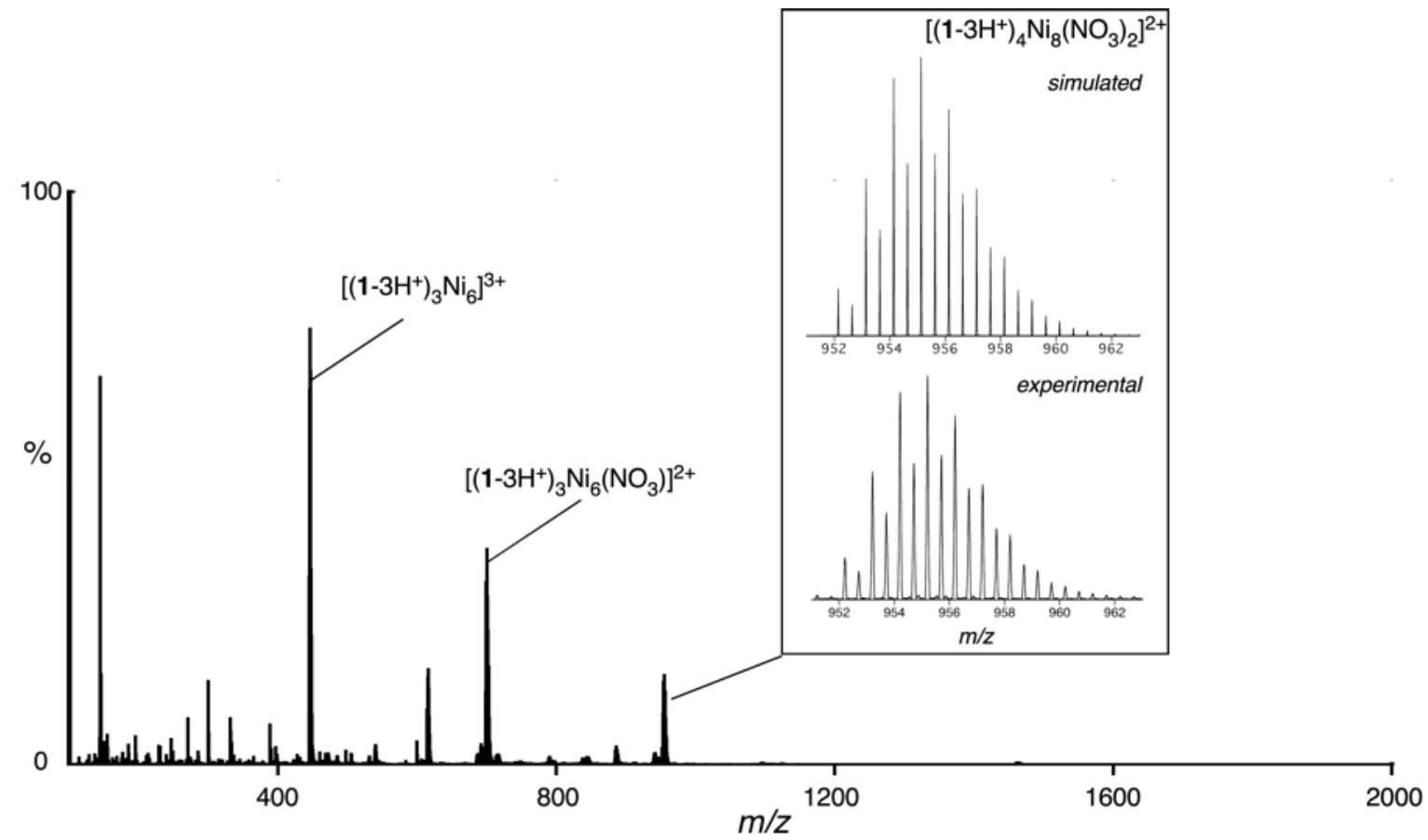

Figure S23. ESI-TOF mass spectrum of the $\left(1-3 \mathrm{H}^{+}\right)_{4} \mathrm{Ni}_{8}\left(\mathrm{NO}_{3}\right)_{4}$ complex in $\mathrm{H}_{2} \mathrm{O}$.

Note: The sample of the $\left(1-3 \mathrm{H}^{+}\right)_{4} \mathrm{Ni}_{8}\left(\mathrm{NO}_{3}\right)_{4}$ complex in Figure S23 was prepared by dilution of its DMSO solution with $\mathrm{H}_{2} \mathrm{O}$.

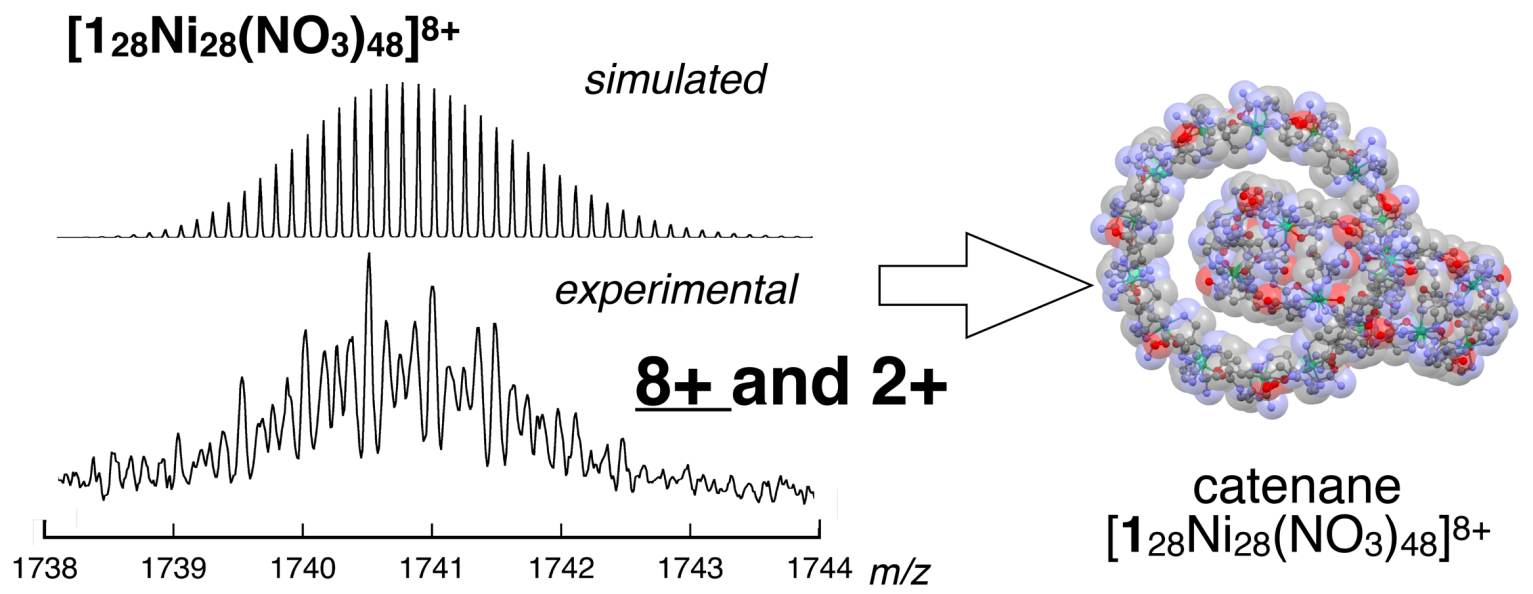

Figure S24. Preliminary CSI-TOF mass spectrum of the needle-like crystals, in which the catenane structure was observed $\left(\mathrm{H}_{2} \mathrm{O} / \mathrm{CH}_{3} \mathrm{CN}, v / v=1\right)$.

Note: Although the observed pattern reveals a mixture of $8^{+}$and $2^{+}$(and more) species, the isotopic pattern of the $8^{+}$species is in agreement with the simulated pattern of the catenane structure $\left(\left[\mathbf{1}_{28} \mathrm{Ni}_{28}\left(\mathrm{NO}_{3}\right)_{48}\right]^{8+}\right)$. This result suggests that the formation of the catenane structure, considering that the experimental conditions (i.e. the inclusion of water in solution) are not suitable for mass observation of giant assembled structures. We thank to Bruker Japan for providing CSI-TOF mass measurement. 


\section{References:}

S1: Miyake, R.; Tashiro, S.; Shiro, M.; Tanaka, K.; Shionoya, M. Ni(II)-Mediated Self-Assembly of Artificial $\beta$-Dipeptides Forming a Macrocyclic Tetranuclear Complex with Interior Spaces for In-Line Molecular Arrangement, J. Am. Chem. Soc. 2008, 130, 5646-5647.

S2: a) Sheldrick, G. M., SADABS, Program for scaling and correction of area detector data, University of Göttingen (Germany), 1996, b) Krause, L; Herbst-Irmer, R.; Sheldrick, G. M.; Stalk, D. Comparison of silver and molybdenum microfocus X-ray sources for single-crystal structure determination, J. Appl. Cryst. 2015, 48, 3-10, c) Sheldrick, G. M. Crystal structure refinement with SHELXL, Acta Cryst. C. 2015, 71, 3-8, d) Spek, A. L., PLATON SQUEEZE: a tool for calculation of the disordered solvent contribution to the calculated structure factors, Acta Cryst. C. 2015, 71. 9-18. 